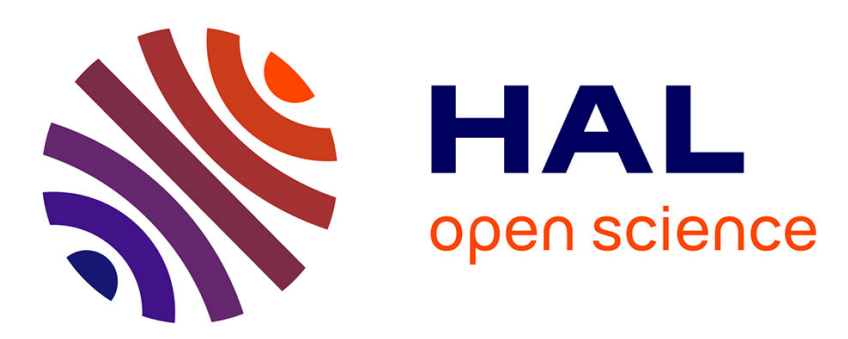

\title{
Would nonprofit workers accept to earn less? Evidence from France
}

Mathieu Narcy

\section{To cite this version:}

Mathieu Narcy. Would nonprofit workers accept to earn less? Evidence from France. Applied Economics, 2009, 43 (3), pp.313. 10.1080/00036840802570447 . hal-00582285

\section{HAL Id: hal-00582285 \\ https://hal.science/hal-00582285}

Submitted on 1 Apr 2011

HAL is a multi-disciplinary open access archive for the deposit and dissemination of scientific research documents, whether they are published or not. The documents may come from teaching and research institutions in France or abroad, or from public or private research centers.
L'archive ouverte pluridisciplinaire HAL, est destinée au dépôt et à la diffusion de documents scientifiques de niveau recherche, publiés ou non, émanant des établissements d'enseignement et de recherche français ou étrangers, des laboratoires publics ou privés. 


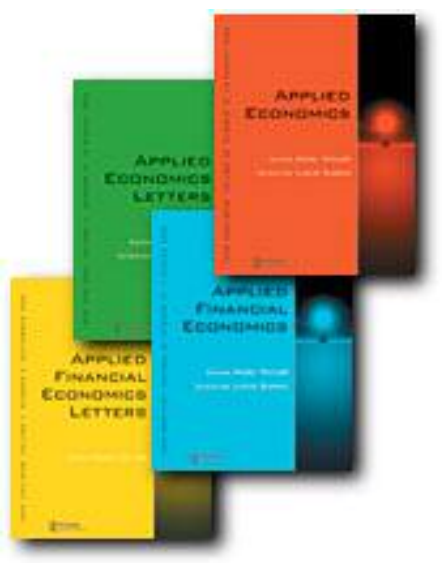

Would nonprofit workers accept to earn less? Evidence from France

\begin{tabular}{|c|c|}
\hline Journal: & Applied Economics \\
\hline Manuscript ID: & APE-07-0755.R1 \\
\hline Journal Selection: & Applied Economics \\
\hline $\begin{array}{r}\text { Date Submitted by the } \\
\text { Author: }\end{array}$ & 05-May-2008 \\
\hline \multirow[t]{2}{*}{ Complete List of Authors: } & NARCY, Mathieu; Centre d'études de I'emploi \\
\hline & $\begin{array}{l}\text { J31 - Wage Level, Structure; Differentials by Skill, Occupation, etc. } \\
<\text { J3 - Wages, Compensation, and Labor Costs }<\text { J - Labor and } \\
\text { Demographic Economics, L31 - Nonprofit Institutions < L3 - } \\
\text { Nonprofit Organizations and Public Enterprise < L - Industrial } \\
\text { Organization }\end{array}$ \\
\hline Keywords: & $\begin{array}{l}\text { J31 - Wage Level, Structure; Differentials by Skill, Occupation, etc. } \\
<\text { J3 - Wages, Compensation, and Labor Costs }<\text { J - Labor and } \\
\text { Demographic Economics, L31 - Nonprofit Institutions < L3 - } \\
\text { Nonprofit Organizations and Public Enterprise }<\text { L - Industrial } \\
\text { Organization }\end{array}$ \\
\hline
\end{tabular}

\section{S) ScholaroNE \\ Manuscript Central}




\title{
Would nonprofit workers accept to earn less? Evidence from France
}

\author{
Mathieu NARCY \\ CEE and ERMES. \\ CEE - "Le Descartes I", 29 promenade Michel Simon, 93166 Noisy Le Grand, France. \\ Tel : +33(0)1 45926958 - Email : mathieu.narcy@cee.enpc.fr
}

\begin{abstract}
This paper focuses on wage differentials between french nonprofit, for-profit and public sectors. Considering the public sector allows to test more extensively the labor donation theory (Preston, 1989). The findings support this theory because nonprofit workers accept to earn significantly less than they would earn in the for-profit and public sectors. They also suggest differences in the motivations of workers in these sectors. Nonprofit workers are attracted to their work for reasons transcending material compensation.
\end{abstract}




\section{Introduction}

The nonprofit sector constitutes a significant and expanding segment of the French economy. Today, it generates around $3.2 \%$ of the gross national product. It is also a large employer with a total of more than one million full-time equivalent paid workers, a share of $5 \%$ of the total salaries in all industries ${ }^{1}$. This total employment increased by $19.4 \%$ between 1999 and 2005 . Although the nonprofit employment is very important in France, very little attention has been paid to the compensation of nonprofit workers. This paper aims to fill this gap.

Nonprofit organizations are characterized by the "nondistribution constraint", i.e. the prohibition to distribute profits to those who are in charge of the organization (Hansman, 1980). Moreover, their objectives are to produce goods and services that generate social benefits and/or to insure the consumer to receive high quality products and services in markets characterized by informational asymmetries. In fact, nonprofit organizations often dominate human and social services aspects of our economy. These characteristics of nonprofit sector are assumed to have effect on the labor market. Wages paid in nonprofit organizations should vary from those paid in comparable for-profit and public organizations.

Labor donation theory (Preston, 1989) postulates that both the moral and ethical goals of nonprofit organizations and the nature of their goods and services aimed at generating social benefits will attract workers who have a lower interest in monetary rewards. Consequently, they may be willing to work at nonprofit organizations at a lower wage than they could have obtained elsewhere because they derive a compensating utility from assisting with production in which they find social value.

Many American studies estimated the wage differential between the nonprofit and for-profit sectors in order to test the labor donation theory ${ }^{2}$. These studies obtained equivocal results. Some of them support Preston's theory while others do not. Among these studies, few addressed self-selection of workers into sector although selectivity bias may account for a portion of the wage differential.

\footnotetext{
${ }^{1}$ Nonprofit organizations are also an important part of the American economy. In 1995, there were 9.6 million full-time equivalent paid workers in nonprofit sector and nonprofit employment accounted for $8.8 \%$ of the gross national product (see Salamon et al., 1999).

${ }^{2}$ See, for example, Preston (1989), Holtmann and Idson (1993), Hallock (2000), Ruhm and Borkoski (2003), Mocan and Teikin (2003).
} 
Moreover, all these studies assumed that each worker onliy faces two choices working in the nonprofit sector or working in the for-profit sector - and disregarded the possibility that workers may decide to be employed in the public sector.

This paper focuses on wage differentials between nonprofit, for-profit and public sectors while allowing for the endogeneity of sector choice. Considering the public sector is useful for at least two reasons. First, it allows to test more extensively the labor donation theory. In fact, nonprofit workers really "donate labor" to their employers by accepting reduced compensation if they earn less in the nonprofit sector than they would earn not only in the for-profit sector but also in the public sector. Second, to take all workers employment opportunity into consideration leads to a better selection bias correction when we will estimate the wage equations and the wage differentials between sectors.

Using the French Labor Force Survey over the 1994-2001 period, a multinomial logit selection model is estimated in order to study the wage differentials between nonprofit, for-profit and public sectors. This research is original for at least two reasons. First, to the best our knowledge, it is the first to estimate the wage differentials between these three sectors while correcting selection bias. Some studies have analyzed the selectivity-corrected wage differential between public and for-profit sectors (see, for example, Hartog and Oosterbeek, 1993; Dustmann and Van Soest, 1998) and others between nonprofit and for-profit sectors (Preston, 1989; Holtmann and Idson, 1993) but none has brough them together. Second, although there is a little research on nonprofit workers compensation in the United States, there is almost none in other countries, especially in France.

This paper is structured as follows. The next section briefly presents the Preston's labor donation model. Section 3 outlines the empirical model used that explicitly addresses the endogeneity bias that may arise through the simultaneity of sector choice and wages. The empirical results are presented in section 5. Finally, section 6 offers concluding comments. 


\section{Labor donation model}

The labor donation model has been formalized by Preston (1989). She postulates that all productive organizations produce a good that generates private and social benefits. The latter are defined as "social externalities, benefits enjoyed by parties external to the transaction or, more specifically, by society as a whole" and have a flavour of public goods.

The utility of each worker is assumed to be positively related to his labor income and the extent of the social benefits $(S B)$ generated by his employer:

$$
U_{i}=U_{i}(w, S B)
$$

with $U_{w}>0$ and $U_{S B}>0$

Along the indifference curve, all workers are then ready to substitute social benefits to his wage:

$$
\frac{\delta w}{\delta S B} \mid \bar{U}<0
$$

Workers are likely to donate labor, exchange wages against social benefits. In the literature, the labor donation theory has only been tested by estimating the wage differential between nonprofit and for-profit sectors. Indeed, nonprofit organizations are hypothesized to produce more social benefits by nature than for-profit firms because they are more present in sectors like education, health and social services. Consequently, nonprofit organizations will be able to attract the workers with the highest rate of substitution between wages and social benefits by paying lower wages. After self-selection of the workers in their preferred sector, the wage differential between nonprofit and for-profit sectors should be negative. However, the labor donation theory has never been empirically tested by considering public sector in addition to these two sectors.

According to François and Vlassopoulos (2007), the workers' inclination to donate labor is related to the way the organization in which they work takes advantage on their donated contribution. Indeed, the workers care about the value of the good and service to which they contribute. In this sense, nonprofit organizations may have a distinct advantage from public and for-profit organizations in generating social benefits. At first, contrary to for-profit counterparts, the nonprofit and public employees do not fear that their "labor donations" are expropriated by a residual 
claimant to raise profits. Next, the managers of nonprofit firms have more flexibility than government bureaucrats "in choosing the mission and provided services tailored to the needs of the local community" (François and Vlassopoulos, 2007). In fact, they are appointed by the community whereas government bureaucrats obey elected politicians and, as a result, might take actions that encourage the likelihood of reelection. In the end, we can hypothesize that nonprofit workers may accept to earn less than the would earn in for-profit and nonprofit sectors. The study of wage differentials between these three sectors may therefore allow us to explore this hypothesis.

Contrary to the labor donation theory, there are other theoretical reasons to expect that nonprofit organizations pay higher wages to comparable workers than their for-profit counterparts. According to the theory of property rights, nonprofit organizations will be less prone to minimize costs than for-profit organizations because of nondistribution constraint. In this case, the relatively high wages observed in nonprofit sector represent rent-sharing due to attenuated property rights. Another rational for wages to be higher in the nonprofit sector can be found in the efficiency wage theory. Under the assumption that performance is more difficult to control in nonprofit organizations than in for-profit organizations, the efficiency wage hypothesis argues that this problem may be partially resolved by a wage in excess.

\section{Multinomial logit selection model}

The model used to estimate the wage differentials between the different sectors is a multinomial logit selection model ${ }^{3}$. This model permits us to deal with two distinct problems. First, separated wage equations are estimated for each sector which allows for the possibility that each worker faces an entirely different wage determination process according to his selected sector. Second, some workers may decide on their sector of employment because of the wage differential while others simply prefer to work in nonprofit organizations for nonwage aspects of the job in accordance with the labor donation theory. The wage equations must be estimatied in

\footnotetext{
${ }^{3}$ This empirical model has been notably used by Gyourko and Tracy (1988) to analyse union wage differentials in the public and private sectors, while controlling for sample selection.
} 
way that accounts for selectivity. In other words, we allow for endogenous selection into sectors.

The multinomial logit selection model can be described as follows. Each worker is assumed to face three mutually exclusive choices: working in the for-profit $\operatorname{sector}(j=f p)$, working in the nonprofit sector $(j=n p)$ and working in the public sector $(j=p u)$. The 'potential' hourly wage for the $i$ th worker in the $j$ th sector is given by

$$
\ln \mathrm{W}_{\mathrm{j}, \mathrm{i}}=\beta_{\mathrm{j}}^{\prime} \mathrm{X}_{\mathrm{i}}+\varepsilon_{\mathrm{j}, \mathrm{i}}
$$

where $X_{i}$ is a vector of job and worker characteristics that affect the log hourly wage $\left(\ln W_{j, i}\right)$ and $\varepsilon_{j, i} \sim N\left(0, \sigma_{j}^{2}\right)$.

However, sector's choice is not exogenous. In fact, individuals are assumed to select the sector that maximizes expected utility. According to the labor donation theory (Preston, 1989), the maximum utility attainable given each sector will be a function of the $\log$ hourly wage $\left(\ln W_{j, i}\right)$ and social benefits $\left(S B_{j}\right)$ offer by each sector. The ith individual's expected utility from working in sector $\mathrm{j}$ is modelled by the index function

$$
I_{j, i}^{*}=\gamma_{j}^{\prime} Z_{i}+\eta_{j, i}
$$

$Z_{i}$ includes all the variables that may determine the log hourly wage $\left(X_{i}\right)$ plus additional variables that reflect the individual's preferences for the sectors and more precisely for social benefits offered by the sectors. The $i$ th individual then compares $I_{j, i}$ for all $j=n p, f p, p u$ and chooses that sector for which $I_{j, i}$ is a maximum. This optimization process is captured by the sector indicator function:

$$
I_{i}=j \quad \text { iff } \quad I_{j, i}^{*}>\max _{k \neq j} I_{k, i}^{*}
$$

Following the formulation in Lee (1983), we define the following residual for each individual and each sector:

$$
u_{j, i}=\max _{k \neq j} I_{k, i}^{*}-\eta_{j, i}
$$

From (5), (6) and (7), we obtain a reformulation of the sector indicator function:

$$
I_{i}=j \quad \text { ssi } \quad u_{j, i}<\gamma_{j}^{\prime} Z_{i}
$$


Then, as shown by Domencich and McFadden (1975), the probability that the sector $\mathrm{s}$ will be chosen is given by ${ }^{4}$

$$
\begin{aligned}
\operatorname{Prob}\left(I_{i}=j\right) & =\operatorname{Prob}\left(u_{j, i}<\gamma_{j}^{\prime} Z_{i}\right) \\
& =\frac{\exp \left(\gamma_{j}^{\prime} Z_{i}\right)}{\sum_{k=1}^{3} \exp \left(\gamma_{k}^{\prime} Z_{i}\right)}
\end{aligned}
$$

The worker's choice of sectors is then analysed with a multinomial logit model. We estimate the wage equation in each sector using the generalized two-step procedure presented in Lee (1983):

$$
\begin{aligned}
E\left(\ln W_{j, i} \mid I_{i}=j\right) & =\beta_{j}^{\prime} X_{i}+E\left(\varepsilon_{j, i} \mid I_{i}=j\right) \\
& =\beta_{j}^{\prime} X_{i}+E\left(\varepsilon_{j, i} \mid u_{j, i}<\gamma_{j}^{\prime} Z_{i}\right) \\
& =\beta_{j}^{\prime} X_{i}-\sigma_{j} \rho_{j} \frac{\phi\left\{\Phi^{-1}\left[F_{j}\left(\gamma_{j}^{\prime} Z_{i}\right)\right]\right\}}{F_{j}\left(\gamma_{j}^{\prime} Z_{i}\right)} \\
& =\beta_{j}^{\prime} X_{i}-\sigma_{j} \rho_{j} \lambda_{j, i}
\end{aligned}
$$

Where $\mathrm{F}$ denotes the multinomial logit distribution function. $\Phi($.$) and \phi($.$) are the$ standard normal distribution and density functions respectively. $\rho_{j}$ is the correlation coefficient between $\eta_{\mathrm{j}, \mathrm{i}}$ and $\varepsilon_{\mathrm{j}, \mathrm{i}} \cdot \sigma_{\mathrm{j}}$ is the standard deviation of the error term $\varepsilon_{j, i}$. $\lambda_{j, i}$ represents the selection term.

The model is estimated in two steps. In the first step, we estimate the multinomial logit model (4) by the logit maximum likelihood method to obtain $\hat{\gamma}_{j}$. In the second step, we estimate equation (9) by ordinary least squares (OLS) after substituting $\hat{\gamma}_{j}$ for $\hat{\gamma}_{j}{ }^{5}$.

\footnotetext{
${ }^{4}$ The disturbances $\eta_{j, i}$ are assumed to be independently and identically distributed with the type I extreme value distribution with cumulative distribution function given by $F\left(\eta_{j, i}<x\right)=\exp [-\exp (x)]$.

${ }^{5}$ The corrected variance-covariance matrix has been derived following the method presented in Lee, Maddala and Trost (1980).
} 
Estimation of the multinomial logit model in the first step is based on the assumption that probabilities of the alternative choices are independent of each other. In other words, removing any of the alternatives in the model should not alter the relative probabilities of choosing the remaining alternatives. This is commonly known as the property of independence from irrelevant alternatives (IIA). Available tests for IIA start from the premise that if a subset of choices is truly irrelevant, omitting them from the model will not change the estimates using the remaining choices systematically. We have chosen to use Small and Hsiao (1985) test for the IIA assumption. Table 1 displays the results concerning this test using specification of equation (4) described in the next section. It appears that the IIA assumption holds in all cases. In other words, adding or deleting choices does not affect the odds among the remaining choices, and the multinomial logit is the correct model choice.

\section{Description of data and variables}

The data used in this study were taken from the 1994-2001 French Labor Force Survey conducted by INSEE ${ }^{6}$. This survey has the advantage of specifically identifying the nonprofit status of worker.

The sample has been selected to include all employees between the ages of 16 and 65 with a permanent contract. Moreover, we have restricted our attention to services sector because nonprofit organizations only move in this sector. In the sector of services, our analysis is also limited to sub-sectors in which the three institutional forms - nonprofit, for-profit and public - coexist ${ }^{7}$. The rationale for the last selection criterion is that we wish to consider homogeneous production techniques and hopefully similar types of jobs. Finally, the working sample consists of 97010 observations. Of these, 11748 refer to individuals in the nonprofit sector, 25030 in the for-profit sector and 60232 in the public sector.

In the wage equations, the dependent variable is the natural logarithm of hourly net wage on the main job. Hourly net wage is calculated as net earnings in the last month (with the exception of special specific wage premia) divided by 4.33

\footnotetext{
${ }^{6}$ INSEE is the French National Institute for Statistics and Economics Studies.

${ }^{7}$ For example, we have excluded sub-sectors like «Transport, storage and communications » and

«Financial intermediation » where nonprofit organizations are almost inactive.
} 
multiplied by the usual weekly working hours. Nominal values are converted into real terms with a base period of 1990. The explanatory variables assumed to influence wages include sex, marital status, number of children, age, dummy variables for education, tenure at current ${ }^{0} b^{8}$, dummy variable indicating if individuals work part-time, occupation, size of firm measured by the number of employees, dummy variable signalling if individuals are employed in the Paris Area, and some working conditions.

The variables included in the choice of the sector equation are the explanatory variables of the potential log hourly net wage 9 . Moreover, to achieve identification of the selection model, it is necessary to include additional variables, called "instruments", that influence sector choice but have no direct effects on wages (i.e., variables in $\mathrm{Z}$ which are not in $\mathrm{X}$ ). Many instruments are suggested.

According to Weisbrod (1983), socioeconomic backgrounds are hypothesized to influence sector's choice. We use the father's occupation as a proxy of socioeconomic backgrounds. We include two dummy variables. The first signals if the worker has a father who works in the public sector. The second indicates if the worker has a father who holds an occupation in the private sector (nonprofit or forprofit) rather directed to social welfare improvement. We expect that the latter variable will positively influence the probability of selecting nonprofit sector.

We also create two variables indicating the proportion of nonprofit employment and the proportion of public employment in the services sector total employment when the worker has been hired in his current job. The idea is that, according to their year of hire, workers may have greater access to nonprofit and public sectors and presumably lower cost of entry.

Finally, we include a dummy variable measuring if the organization offers nonmonthly wage premia. The idea is that nonprofit workers, because of their preferences for social benefits, are less attracted to this kind of reward than their forprofit and public counterparts.

Table 2 offers summary descriptive statistics of the sample by sector. It shows many significant differences between sectors. For example, public workers earn on average 2.7 per cent more than nonprofit workers who, in turn, earn on average 1.9

\footnotetext{
${ }^{8}$ Tenure is obtained as the difference between the year of the survey and the year of the start of the current job.

${ }^{9}$ However, job tenure is not considered in the choice of the sector equation because selection must precede tenure at current job.
} 
per cent more than for-profit workers. There are more part-time workers and female employees in nonprofit sector than in other sectors. Compared to for-profit workers, nonprofit and public workers are older, much more highly educated and have higher job tenure.

\section{Empirical results}

\subsection{Choice equation}

The marginal effect of each variable on the probability of selecting each sector is given in table 3. Several features are worth noting about these effects. As can be seen in the bottom of table 3 , the variables not used in the wage equations have the expected signs. The proportion of nonprofit (respectively public) employment in the services sector total employment influences positively and significantly the probability of selecting the nonprofit (respectively public) sector. Having a father who works in the public (nonprofit) sector is associated with a significantly greater probability of being employed in the public (nonprofit) sector. Other things equal, nonprofit workers are less likely to be attracted by non-monthly wage premia (variable "bonus") compared to their for-profit and public counterparts. This result means that nonprofit organizations attract workers who have lower interest in monetary rewards in accordance with labor donation theory.

The results for the explanatory variables used in the wage equations also merit some remarks. Being employed part-time increases the probability of selecting the nonprofit sector. Youngers are more likely to be for-profit workers. Considering the level of education, estimates show that education significantly increases the individual's likelihood of being employed in the public sector. Managers have a higher probability of selecting the nonprofit sector while being technicians or employees reduces the likelihood of being in the for_profit sector.

Using the estimation procedure presented in section 3 , the results from table 3 (the coefficients but not the marginal effects) are used to estimate the wage equations with selectivity correction. 


\subsection{Wage equations}

The estimation results for the selectivity-corrected wage equations are presented in table 4. Selection terms are statistically significant for the three sectors. The sectors' choice is then endogenous. A negative (positive) estimated coefficient on selection term implies that workers who choose the considered sector have unobserved characteristics which lead them to earn more (less) than a person randomly drawn from the population and assigned to this sector.

The human capital variables have the expected signs in the three sectors. Age and job tenure imply the familiar inverted-U shaped wage profile. Returns to education are similarly positively significant. Female workers, compared to male workers, receive lower wages. Variables like the number of children, or being married, have also a positive impact on wages. The same is true for characteristics like working in the Paris area or in a large firm that imply higher wages.

\subsection{Wage differentials}

Unconditional wage differentials between nonprofit, for-profit and public sectors are presented in figure 1 and are estimated as follows ${ }^{10}$ :

$$
\Delta W_{i \rightarrow j}=\left[\frac{E\left(\ln W_{j} \mid \bar{X}_{i}\right)}{E\left(\ln W_{j} \mid \bar{X}_{i}\right)}-1\right] \times 100=\left[\frac{\exp \left(\hat{\beta}_{j} \bar{X}_{i}\right)}{\exp \left(\hat{\beta}_{i} \bar{X}_{i}\right)}-1\right] \times 100
$$

$\Delta W_{i \rightarrow j}$ compares on average what the workers of sector $i$ would have earned if they had to work in sector $j$ with what they earn in sector $i$. For example, the first wage differential presented in figure $1\left(\Delta W_{p u \rightarrow f p}=+2.4 \%\right)$ compares on average what the public workers $(i=p u)$ would have earned if they had to work in for-profit sector $(j=f p)$ with what they earn in public sector.

The two wage differentials in the bottom of figure 1 support the Preston's theoretical model of section 2 which predicts that nonprofit workers may be willing to work at lower wage than they could have obtained elsewhere. In fact, they would have earned $21.1 \%$ and $27.3 \%$ more if they had to work in public sector and for-

\footnotetext{
${ }^{10}$ In a selection model involving more than two choices, the conditional wage differentials (defined as the difference between a worker's expected wage in his preferred sector and his expected wage in his less preferred sector) cannot be estimated because some of the covariance terms required are not identified (see, Gyourko et Tracy, 1988, pp. 240-241).
} 
profit sector respectively. In contrast, for-profit workers have chosen the best profitable sector. Considering the public workers, they would have obtained a supplementary wage benefit of $2.4 \%$ in joining the for-profit sector and a wage penalty of $21.5 \%$ in joining the nonprofit sector. These results also suggest that nonprofit sector is considered by nonprofit workers as the best provider of social benefits.

\section{Conclusion}

Our aim in this paper was to examine the wage differentials between French nonprofit, for-profit and public sectors in order to test the Preston's labor donation theory. Our results support this theory more extensively than previous American studies which have overlooked the public sector.

The nonprofit sector attracts workers who have a strong commitment to the social objective of the nonprofit organizations and a subordinate interest in monetary gains. Therefore, nonprofit reports may report higher levels of intrinsic motivation than for-profit and public counterparts. Based on the Motivation Crowding-out Theory (Frey, 1997), we argue that nonprofit employers must adopt an approach to human resource management aimed at maintaining the intrinsic motivation of their employees.

\section{Acknowledgements}

We wish to thank J. Lanfranchi and S. Lotz for the useful comments and suggestions. Any remaining errors are ours. 


\section{References}

Domencich, T., and D. McFadden (1975) Urban Travel Demand: A Behavioral Analysis, Amsterdam: North Holland.

Dustmann, C., and A. Van Soest (1998) Public and private sector wages of male workers in Germany, European Economic Review, 42, 1417-41.

François, P., and M. Vlassopoulos (2007), Pro-Social Motivation and the delivery of Social Services, forthcoming in CESifo Economic Studies.

Frey, B.S., (1997) On the relationship between intrinsic and extrinsic work motivation, International Journal of Industrial Organization, 15, 427-39.

Gyourko, J., and J. Tracy (1988) An Analysis of Public- and Private- Sector Wages allowing for Endogenous Choices of both Government and Union Status, Journal of Labor Economics, 6, 229-53.

Hallock, K.F., (2000) Compensation in Nonprofit Organizations, Research in Personnel and Human Resources Management, 19, 243-94.

Hansman, H., (1980) The Role of Nonprofit Enterprise, Yale Law Journal, 89, 835901.

Hartog, J, and H. Oosterbeek (1993) Public and private sector wages in the Netherlands, European Economic Review, 37, 97-114.

Holtmann, A.G., and T.L. Idson (1993) Wage Determination of Registered Nurses in Proprietary and Nonprofit Nurses Homes, Journal of Human Resources, 28, 55-79.

Lee, L.F., (1983) Generalized Econometric Models with Selectivity, Econometrica ,51, 507-12. 
Lee, L.F., Maddala, G.S., and R. Trost (1980) Asymptotic Covariance Matrices of Two-Stage Probit and Two-Stage Tobit Methods for Simultaneous Equations models with Selectivity, Econometrica, 48, 491-503.

Mocan, H.N., and E. Teikin (2003) Nonprofit Sector and Part-Time Work: An Analysis of Employer-Employee Matched Data of Childcare Workers, Review of Economics and Statistics, 85, 38-50.

Preston, A.E., (1989) The Nonprofit Worker in a For-Profit World, Journal of Labor Economics, 7, 438-63.

Ruhm, C.J., and C. Borkoski (2003) Compensation in the Nonprofit Sector, Journal of Human Resources, 38, 992-1021.

Salamon, L.M., Anheir, H.K., List, R., Toepler, S., Sokolowski, W., and Associates (1999) Global Civil Society: Dimensions of the Nonprofit Sector, Johns Hopkins Center for Civil Society Studies: Baltimore, MD.

Small, K.A., and C. Hsiao (1985) Multinomial Logit Specification Tests, International Economic Review, 26, 619-27.

Weisbrod, B.A., (1983) Nonprofit and Proprietary Sector Behavior: Wage Differentials among Lawyers, Journal of Labor Economics, 1, 246-63. 
Table 1 - Small-Hsiao test of the IIA assumption

\begin{tabular}{cccccc}
\hline \hline Sector omitted & $\operatorname{lnL}[$ full] & $\operatorname{lnL}[0 \mathrm{omit}]$ & SH & P>chi2 & Evidence \\
\hline For-profit sector & $-1,03 \mathrm{E}+4$ & $-1,03 \mathrm{E}+4$ & 36,642 & 0,347 & for $\mathrm{H}_{0}$ \\
Nonprofit sector & $-1,67 \mathrm{E}+4$ & $-1,67 \mathrm{E}+4$ & 28,169 & 0,749 & for $\mathrm{H}_{0}$ \\
Public sector & $-7561,21$ & $-7538,78$ & 44,856 & 0,101 & for $\mathrm{H}_{0}$ \\
\hline \hline
\end{tabular}

Source : INSEE, French Labor Force Survey (1994 to 2001)

Note : The basic idea of the Small and Hsiao (1985) test is that if the IIA assumption holds, the loglikelihood for the unrestricted model ( $\operatorname{lnL}[$ full]) will not be very different from the log-likelihood for the restricted model ( $\operatorname{lnL}[\mathrm{omit}])$. This latter model is created by dropping one choice alternative.

The hypotheses are:

$\mathrm{H}_{0}$ : IIA assumption is not violated.

$\mathrm{H}_{1}$ : IIA assumption is violated.

The test statistics is:

$$
\mathrm{SH}=-2[\operatorname{lnL}[\text { full] }-\operatorname{lnL}[\mathrm{omit}]]
$$

SH is asymptotically chi-square distributed with degrees of freedom equal to the number of independent variables plus one. 
Table 2 - Descriptive statistics

\begin{tabular}{|c|c|c|c|}
\hline Variable & $\begin{array}{c}\text { Nonprofit } \\
\text { sector }\end{array}$ & $\begin{array}{c}\text { For-profit } \\
\text { sector }\end{array}$ & $\begin{array}{l}\text { Public } \\
\text { sector }\end{array}$ \\
\hline Log net hourly wage & 3.70 & 3.63 & 3.80 \\
\hline (in 1990 French Francs) & $(0.32)$ & $(0.33)$ & $(0.32)$ \\
\hline Part-time work (\%) & 21.6 & 15.8 & 12.1 \\
\hline Female $(\%)$ & 71.7 & 63.2 & 64.2 \\
\hline Married or cohabiting (\%) & 73.6 & 71.5 & 75.6 \\
\hline Number of children & $\begin{array}{c}0.8 \\
(1.0)\end{array}$ & $\begin{array}{c}0.8 \\
(1.0)\end{array}$ & $\begin{array}{c}0.8 \\
(1.0)\end{array}$ \\
\hline Age (years) & $\begin{array}{l}40.8 \\
(9.6)\end{array}$ & $\begin{array}{l}37.3 \\
(9.8)\end{array}$ & $\begin{array}{l}41.6 \\
(9.3)\end{array}$ \\
\hline Job tenure (years) & $\begin{array}{c}9.5 \\
(7.9)\end{array}$ & $\begin{array}{c}7.6 \\
(7.8)\end{array}$ & $\begin{array}{l}13.3 \\
(9.6)\end{array}$ \\
\hline \multicolumn{4}{|l|}{ Qualifications (\%): } \\
\hline No qualification & 20.8 & 20.7 & 19.6 \\
\hline General lower secondary & 6.6 & 8.0 & 7.2 \\
\hline Vocational lower secondary & 26.1 & 30.1 & 26.3 \\
\hline High school degree & 13.3 & 16.1 & 13.3 \\
\hline Undergraduate level & 21.9 & 16.2 & 19.1 \\
\hline Above undergraduate & 11.3 & 8.9 & 14.5 \\
\hline \multicolumn{4}{|l|}{ Occupations (\%) : } \\
\hline Blue-collar & 10.5 & 17.4 & 11.1 \\
\hline Employee & 42.8 & 46.6 & 43.1 \\
\hline Technicians, supervisors & 36.7 & 24.7 & 32.2 \\
\hline Managers & 10.0 & 11.3 & 13.6 \\
\hline \multicolumn{4}{|l|}{ Firm sizes $(\%)$ : } \\
\hline $1-9$ & 25.4 & 37.7 & 37.2 \\
\hline $10-49$ & 23.7 & 22.7 & 9.8 \\
\hline $50-499$ & 32.1 & 22.1 & 21.0 \\
\hline$>499$ & 18.8 & 17.5 & 32.0 \\
\hline Employed in the Paris area (\%) & 12.4 & 22.0 & 12.6 \\
\hline \multicolumn{4}{|l|}{ Working conditions (\%): } \\
\hline Night work & 10.7 & 14.1 & 13.84 \\
\hline Shift work & 7.4 & 6.3 & 8.30 \\
\hline Sunday work & 32.0 & 31.4 & 36.03 \\
\hline Variable working time & 30.5 & 28.2 & 26.43 \\
\hline Nonprofit employment (\%) & 8.5 & 8.8 & 7.6 \\
\hline Public employment (\%) & 39.1 & 36.1 & 44.8 \\
\hline \multicolumn{4}{|l|}{ Father's occupation (\%) : } \\
\hline Public sector & 14.2 & 13.0 & 17.9 \\
\hline Nonprofit sector (approximation) & 34.8 & 30.1 & 32.1 \\
\hline Bonus $(\%)$ & 35.9 & 46.9 & 51.4 \\
\hline $\mathbf{N}$ & 11748 & 25030 & 60232 \\
\hline
\end{tabular}

Source : INSEE, French Labor Force Survey (1994 to 2001)

Note : Standard deviations are in parentheses. 
Table 3 - Multinomial logit sector choice model (marginal effects)

\begin{tabular}{|c|c|c|c|c|c|c|}
\hline \multirow[t]{2}{*}{ Variable } & \multicolumn{2}{|c|}{ Nonprofit sector } & \multicolumn{2}{|c|}{ For-profit sector } & \multicolumn{2}{|c|}{ Public sector } \\
\hline & Coef. & t-value & Coef. & t-value & Coef. & t-value \\
\hline Intercept & -0.505 & $(23.18)$ & 0.696 & $(23.63)$ & -0.191 & $(5.58)$ \\
\hline Part-time work & 0.032 & $(11.46)$ & -0.018 & $(5.94)$ & $-0.006 *$ & $(1.29)$ \\
\hline Female & 0.023 & $(9.42)$ & 0.014 & $(4.10)$ & -0.037 & $(9.54)$ \\
\hline Married or cohabiting & $0.001 *$ & $(0.26)$ & 0.011 & $(3.11)$ & -0.011 & $(2.86)$ \\
\hline Number of children & -0.005 & $(4.19)$ & -0.009 & $(5.52)$ & 0.014 & $(7.45)$ \\
\hline Age & 0.004 & (4.68) & -0.019 & $(15.05)$ & 0.015 & $(9.95)$ \\
\hline $\mathrm{Age}^{2} / 100$ & -0.003 & $(2.63)$ & 0.020 & $(12.49)$ & -0.017 & (9.17) \\
\hline \multicolumn{7}{|l|}{ Qualifications: } \\
\hline No qualification & Ref. & & Ref. & & Ref. & \\
\hline $\begin{array}{l}\text { General lower } \\
\text { secondary }\end{array}$ & $-0.002 *$ & $(0.42)$ & 0.016 & $(2.70)$ & -0.014 & $(2.04)$ \\
\hline $\begin{array}{l}\text { Vocational lower } \\
\text { secondary }\end{array}$ & 0.009 & $(2.91)$ & $0.007 *$ & $(1.80)$ & -0.016 & (3.37) \\
\hline High school degree & $-0.001 *$ & $(0.42)$ & $0.008^{*}$ & (1.48) & $-0.008 *$ & $(1.24)$ \\
\hline Undergraduate level & $0.006 *$ & (1.63) & -0.050 & $(8.74)$ & 0.044 & $(6.67)$ \\
\hline $\begin{array}{l}\text { Above } \\
\text { undergraduate }\end{array}$ & -0.014 & $(2.92)$ & -0.181 & $(24.71)$ & 0.195 & $(23.84)$ \\
\hline \multicolumn{7}{|l|}{ Occupations: } \\
\hline Blue-collar & Ref. & & Ref. & & Ref. & \\
\hline Employee & 0.013 & $(3.63)$ & -0.072 & $(15.60)$ & 0.059 & $(10.55)$ \\
\hline $\begin{array}{l}\text { Technicians, } \\
\text { supervisors }\end{array}$ & 0.053 & (12.83) & -0.084 & $(15.29)$ & 0.030 & $(4.70)$ \\
\hline Managers & 0.022 & $(3.95)$ & $-0.003 *$ & $(0.37)$ & -0.019 & $(2.24)$ \\
\hline \multicolumn{7}{|l|}{ Firm sizes : } \\
\hline $1-9$ & Ref. & & Ref. & & Ref. & \\
\hline $10-49$ & 0.103 & $(35.70)$ & 0.099 & $(24.08)$ & -0.202 & $(42.21)$ \\
\hline $50-499$ & 0.087 & $(33.09)$ & -0.018 & $(4.77)$ & -0.069 & (15.97) \\
\hline$>499$ & $0.020 *$ & $(6.62)$ & -0.113 & $(28.05)$ & 0.092 & $(20.50)$ \\
\hline $\begin{array}{l}\text { Employed in the Paris } \\
\text { area }\end{array}$ & -0.009 & $(2.84)$ & 0.133 & $(35.41)$ & -0.124 & $(27.12)$ \\
\hline \multicolumn{7}{|l|}{ Working conditions : } \\
\hline Night work & -0.020 & $(5.65)$ & 0.039 & $(8.28)$ & 0.019 & $(3.50)$ \\
\hline Shift work & 0.023 & $(5.46)$ & -0.020 & (3.34) & $-0.002 *$ & $(0.37)$ \\
\hline Sunday work & -0.012 & $(4.95)$ & -0.040 & $(11.04)$ & 0.052 & (12.78) \\
\hline $\begin{array}{l}\text { Variable working } \\
\text { time }\end{array}$ & 0.025 & $(10.74)$ & 0.030 & $(8.76)$ & -0.055 & $(14.12)$ \\
\hline Nonprofit employment & 0.020 & $(19.62)$ & $-0.002 *$ & $(1.60)$ & -0.018 & $(11.02)$ \\
\hline Public employment & 0.002 & $(2.93)$ & -0.007 & $(32.04)$ & 0.007 & (26.46) \\
\hline \multicolumn{7}{|l|}{ Father's occupation : } \\
\hline Public sector & -0.011 & $(3.70)$ & -0.062 & $(14.66)$ & 0.073 & (15.39) \\
\hline Nonprofit sector & 0.009 & $(3.75)$ & -0.017 & $(5.45)$ & 0.009 & $(2.48)$ \\
\hline Bonus & -0.055 & $(25.54)$ & 0.036 & $(12.06)$ & 0.018 & $(5.37)$ \\
\hline Log likelihood & \multicolumn{6}{|c|}{-77959.75} \\
\hline $\mathrm{N}$ & \multicolumn{6}{|c|}{97010} \\
\hline
\end{tabular}


Table 4 - Wage equations estimates with selectivity correction by sector of employment

\begin{tabular}{|c|c|c|c|c|c|c|}
\hline \multirow[t]{2}{*}{ Variables } & \multicolumn{2}{|c|}{ Nonprofit sector } & \multicolumn{2}{|c|}{ For-profit sector } & \multicolumn{2}{|c|}{ Public sector } \\
\hline & Coef. & t-value & Coef. & t-value & Coef. & t-value \\
\hline Intercept & 2.548 & $(87.12)$ & 2.778 & $(92.80)$ & 2.959 & $(95.67)$ \\
\hline Part-time work & $0.006^{*}$ & $(0.11)$ & $-0.019 *$ & $(0.81)$ & $-0.020 *$ & $(0.78)$ \\
\hline Female & -0.064 & (6.99) & -0.068 & $(11.81)$ & -0.061 & $(17.68)$ \\
\hline Married or cohabiting & 0.023 & $(4.23)$ & 0.011 & $(3.44)$ & 0.018 & $(9.17)$ \\
\hline Number of children & $0.008 *$ & $(1.70)$ & 0.013 & $(3.97)$ & 0.019 & $(9.87)$ \\
\hline Age & 0.020 & $(6.44)$ & 0.025 & $(12.48)$ & 0.015 & $(9.75)$ \\
\hline $\mathrm{Age}^{2} / 100$ & -0.018 & $(8.06)$ & -0.025 & $(15.37)$ & -0.013 & (12.83) \\
\hline Job tenure & 0.012 & $(5.11)$ & 0.014 & $(8.66)$ & 0.012 & $(13.51)$ \\
\hline $\mathrm{Job}_{\text {tenure }}^{2} / 100$ & -0.012 & $(13.75)$ & -0.007 & $(9.92)$ & -0.009 & $(20.33)$ \\
\hline \multicolumn{7}{|l|}{ Qualifications : } \\
\hline No qualification & \multicolumn{2}{|c|}{ Ref. } & \multicolumn{2}{|c|}{ Ref. } & \multicolumn{2}{|c|}{ Ref. } \\
\hline $\begin{array}{l}\text { General lower } \\
\text { secondary }\end{array}$ & 0.124 & $(20.41)$ & 0.068 & $(17.11)$ & 0.095 & $(39.61)$ \\
\hline $\begin{array}{l}\text { Vocational lower } \\
\text { secondary }\end{array}$ & 0.155 & $(20.01)$ & 0.082 & $(16.90)$ & 0.087 & $(28.20)$ \\
\hline High school degree & 0.219 & $(28.67)$ & 0.138 & $(24.90)$ & 0.160 & $(47.46)$ \\
\hline Undergraduate level & 0.294 & (31.02) & 0.224 & $(23.20)$ & 0.229 & $(45.22)$ \\
\hline $\begin{array}{l}\text { Above } \\
\text { undergraduate }\end{array}$ & 0.304 & $(51.61)$ & 0.290 & $(68.72)$ & 0.276 & (97.90) \\
\hline \multicolumn{7}{|l|}{ Occupations: } \\
\hline Blue-collar & \multicolumn{2}{|c|}{ Ref. } & \multicolumn{2}{|c|}{ Ref. } & \multicolumn{2}{|c|}{ Ref. } \\
\hline Employee & 0.069 & $(7.71)$ & 0.047 & $(8.17)$ & 0.027 & $(7.78)$ \\
\hline $\begin{array}{l}\text { Technicians, } \\
\text { supervisors }\end{array}$ & 0.270 & $(25.11)$ & 0.225 & (34.83) & 0.223 & $(50.67)$ \\
\hline Managers & 0.393 & $(36.45)$ & 0.403 & $(62.59)$ & 0.367 & $(83.58)$ \\
\hline \multicolumn{7}{|l|}{ Firm sizes : } \\
\hline $1-9$ & \multicolumn{2}{|c|}{ Ref. } & \multicolumn{2}{|c|}{ Ref. } & \multicolumn{2}{|c|}{ Ref. } \\
\hline $10-49$ & 0.070 & (9.13) & $0.007 *$ & $(1.47)$ & -0.012 & $(3.92)$ \\
\hline $50-499$ & 0.084 & $(10.15)$ & 0.038 & (7.97) & $0.007 *$ & (1.43) \\
\hline$>499$ & 0.093 & (11.54) & 0.070 & (18.13) & 0.020 & $(24.28)$ \\
\hline $\begin{array}{l}\text { Employed in the Paris } \\
\text { area }\end{array}$ & 0.092 & $(12.75)$ & 0.101 & $(21.83)$ & 0.061 & $(7.79)$ \\
\hline \multicolumn{7}{|l|}{ Working conditions : } \\
\hline Night work & 0.030 & (3.66) & $0.009 *$ & $(1.56)$ & 0.049 & $(15.39)$ \\
\hline Shift work & 0.044 & $(8.78)$ & 0.016 & $(4.05)$ & 0.032 & $(14.77)$ \\
\hline Sunday work & 0.030 & $(6.11)$ & $0.003 *$ & $(1.01)$ & 0.043 & (20.18) \\
\hline $\begin{array}{l}\text { Variable working } \\
\text { time }\end{array}$ & $-0.012 *$ & (1.66) & -0.017 & $(2.93)$ & 0.010 & $(3.85)$ \\
\hline Selection term & -0.087 & (6.19) & 0.099 & $(15.60)$ & 0.044 & $(3.72)$ \\
\hline $\mathrm{R}^{2}$ & \multicolumn{2}{|c|}{0.56} & \multicolumn{2}{|c|}{0.60} & \multicolumn{2}{|c|}{0.65} \\
\hline $\mathrm{N}$ & \multicolumn{2}{|c|}{11748} & \multicolumn{2}{|c|}{25030} & \multicolumn{2}{|c|}{60232} \\
\hline
\end{tabular}

Source : INSEE, French Labor Force Survey (1994 to 2001)

Note: The specification includes a set of industry and year dummies. Absolute t-values are in parentheses. $*$ not significant at $5 \%$. 
Figure 1 - What the workers would have earned if they had to work in an another sector

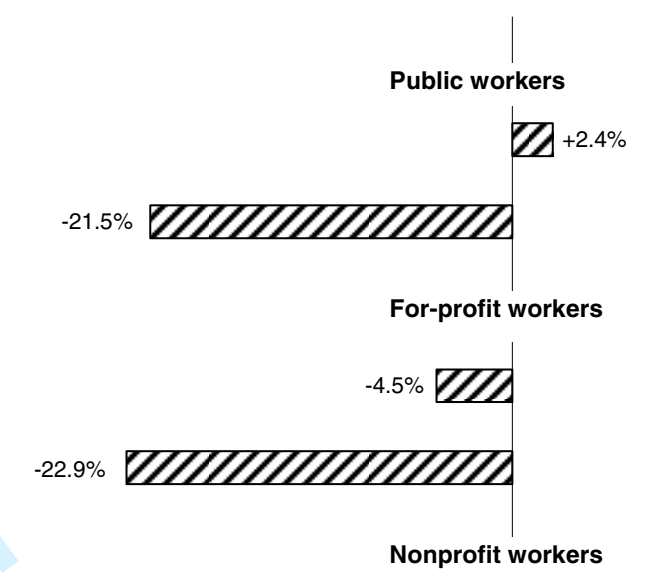

a Nonprofit sector

च Public sector

DIIIIIIIIIIII +21.1\%

\ For-profit sector

ZIIIIIIIIIIIIIIIII +27.3\%

Note : All the differentials are significant at $5 \%$ level.

Lecture : The public workers would have earned $2.4 \%$ more if they had to work in nonprofit sector. 


\title{
Would nonprofit workers accept to earn less? Evidence from France
}

\author{
Mathieu NARCY \\ CEE, ERMES and TEPP (FR $\left.n^{\circ} 3126, C N R S\right)$ \\ CEE - “Le Descartes I", 29 promenade Michel Simon, 93166 Noisy Le Grand, France. \\ Tel : +33(0)1 45926958 - Email : mathieu.narcy@cee.enpc.fr
}

\begin{abstract}
This paper focuses on wage differentials between French nonprofit, for-profit and public sectors. Considering the public sector allows testing more extensively the labour donation theory (Preston, 1989). The findings support this theory because nonprofit workers accept to earn significantly less than they would earn in the forprofit and public sectors. They also suggest differences in the motivations of workers in these sectors. Nonprofit workers are attracted to their work for reasons transcending material compensation.
\end{abstract}




\section{Introduction}

The nonprofit sector constitutes a significant and expanding segment of the French economy. Today, it generates around $3.2 \%$ of the gross national product. It is also a large employer with a total of more than one million full-time equivalent paid workers, a share of $5 \%$ of the total salaries in all industries ${ }^{1}$. This total employment increased by $19.4 \%$ between 1999 and 2005 . Although the nonprofit employment is very important in France, very little attention has been paid to the compensation of nonprofit workers. This paper aims to fill this gap.

Nonprofit organizations are characterized by the "nondistribution constraint", i.e. the prohibition to distribute profits to those who are in charge of the organization (Hansman, 1980). Moreover, their objectives are to produce goods and services that generate social benefits and/or to insure the consumer to receive high quality products and services in markets characterized by informational asymmetries. In fact, nonprofit organizations often dominate human and social services aspects of our economy. These characteristics of nonprofit sector are assumed to have effect on the labour market. Wages paid in nonprofit organizations should vary from those paid in comparable for-profit and public organizations.

Labour donation theory (Preston, 1989) postulates that both the moral and ethical goals of nonprofit organizations and the nature of their goods and services aimed at generating social benefits will attract workers who have a lower interest in monetary rewards. Consequently, they may be willing to work at nonprofit organizations at a lower wage than they could have obtained in for-profit organizations because they derive a compensating utility from assisting with production in which they find social value. Nonprofit workers may then report higher levels of pro-social motivation and importance of work relative to money in their occupations than for-profit counterparts. This motivation is similar to an intrinsic motivation in the sense it doesn't stem from the pecuniary or other material rewards that a worker may receive from outside (François and Vlassopoulos, 2007).

\footnotetext{
${ }^{1}$ Nonprofit organizations are also an important part of the American economy. In 1995, there were 9.6 million full-time equivalent paid workers in nonprofit sector and nonprofit employment accounted for $8.8 \%$ of the gross national product (see Salamon et al., 1999).
} 
Many American studies estimated the wage differential between the nonprofit and for-profit sectors in order to test the labour donation theory ${ }^{2}$. These studies obtained equivocal results. Some of them support Preston's theory while others do not. Among these studies, few addressed self-selection of workers into sector although selectivity bias may account for a portion of the wage differential. Moreover, all these studies assumed that each worker only faces two choices working in the nonprofit sector or working in the for-profit sector - and disregarded the possibility that workers may decide to be employed in the public sector.

This paper focuses on wage differentials between nonprofit, for-profit and public sectors while allowing for the endogeneity of sector choice. Using the French Labour Force Survey over the 1994-2001 period, a multinomial logit selection model is estimated. This research is original for at least three reasons.

First, although there is a little research on nonprofit workers compensation in the United States, there is almost none in other countries, especially in France.

Second, to the best our knowledge, it is the first to estimate the wage differentials between these three sectors while correcting selection bias. Some studies have analyzed the selectivity-corrected wage differential between public and forprofit sectors (see, for example, Hartog and Oosterbeek, 1993; Dustmann and Van Soest, 1998; Prescott and Wandschneider, 1999) and others between nonprofit and for-profit sectors (Preston, 1989; Holtmann and Idson, 1993; Nogushi, Shimizutani and Suzuki, 2008) but none has brough them together. Considering the nonprofit, for-profit and public sectors is useful because it allows testing more extensively the labour donation theory. In fact, nonprofit workers really "donate labour" to their employers by accepting reduced compensation if they earn less in the nonprofit sector than they would earn not only in the for-profit sector but also in the public sector.

Third, very little is known about the pay differential between public and nonprofit sectors in France and in other countries. This paper also aims to fill this gap. While public and nonprofit sectors differ from for-profit one in several dimensions through which wage setting may be affected, the differences between public and nonprofit sectors are less clear. More particularly, like nonprofit firms, public organizations may also receive labour donations because they produce output

\footnotetext{
${ }^{2}$ See, for example, Preston (1989), Holtmann and Idson (1993), Hallock (2000), Ruhm and Borkoski (2003), Mocan and Teikin (2003).
} 
that is socially valued. The estimation of wage differential between nonprofit and public sectors may shed new light on differences in pro-social motivation of workers in these two sectors.

This paper is structured as follows. The next section presents the different theoretical explications for the existence of wage differentials between nonprofit, forprofit and public sectors and, more particularly, the Preston's labour donation model. Section 3 outlines the empirical model used that explicitly addresses the endogeneity bias that may arise through the simultaneity of sector choice and wages. The empirical results are presented and discussed in section 5. Finally, section 6 offers concluding comments.

\section{Theoretical explanations for the existence of wage differentials between institutional forms}

In this section, we provide an overview of the theories that have been proposed in the literature to explain the existence of wage differentials between nonprofit, forprofit and public sectors. First, we focus on the labour donation theory (Preston, 1989) because it suggests differences in pro-social motivation of workers in these three sectors. While this theory has been typically developed to explain the wage differential between nonprofit and for-profit sectors, we argue that it can be extended in order to analyze, not only the public-for-profit wage differential, but also the public/nonprofit wage differential. Second, we briefly discuss the other theories that can also explain the existence of wage differentials between nonprofit, for-profit and public sectors.

\section{1. Labour donation model}

The labour donation model has been formalized by Preston (1989). She postulates that all productive organizations produce a good that generates private and social benefits. The latter are defined as "social externalities, benefits enjoyed by parties external to the transaction or, more specifically, by society as a whole" and have a flavour of public goods. 
The utility of each worker is assumed to be positively related to his labour income and the extent of the social benefits $(S B)$ generated by his employer:

$$
U_{i}=U_{i}(w, S B)
$$

with $U_{w}>0$ and $U_{S B}>0$

Along the indifference curve, all workers are then ready to substitute social benefits to his wage:

$$
\frac{\delta w}{\delta S B} \mid \bar{U}<0
$$

Workers are likely to donate labour, exchange wages against social benefits. In the literature, the labour donation theory has only been tested by estimating the wage differential between nonprofit and for-profit sectors. Indeed, nonprofit organizations are hypothesized to produce more social benefits by nature than for-profit firms because they are more present in sectors like education, health and social services. Consequently, nonprofit organizations will be able to attract the workers with the highest rate of substitution between wages and social benefits by paying lower wages. After self-selection of the workers in their preferred sector, the wage differential between nonprofit and for-profit sectors should be negative and could signal a greater pro-social motivation among nonprofit workers than among their forprofit counterparts. The labour donation theory has never been empirically tested by considering public sector in addition to these two sectors. However, this theory can be extended to predict on the one hand the public/for-profit wage differential and, on the other hand, the nonprofit-public wage differential.

According to François and Vlassopoulos (2007), the workers' inclination to donate labour is related to not only the quantity of social benefits produced by the organization but also the way the organization in which they work takes advantage on their donated contribution. In this sense, nonprofit and public organizations may have a distinct advantage from for-profit organizations.

First, these two institutional forms are hypothesized to produce output more socially valued compared to the for-profit form.

Second, contrary to for-profit counterparts, the nonprofit and public employees do not fear that their "labour donations" are expropriated by a residual claimant to 
raise profits ${ }^{3}$. This happens because for-profit organizations are unable to credibly ensure that labour donations will not be utilized to enhance profit instead of output. Consequently, like the wage differential between nonprofit and for-profit sectors, the wage differential between public and for-profit sectors should be also negative.

At a theoretical level, the difference between public and nonprofit sectors as providers of social services is not well understood. However, we argue that socially motivated workers may be more prone to donate labour in nonprofit organizations than in public ones. Two main reasons may explain this workers' inclination.

First, if we refer to the 'public goods' theory developed by Weisbrod (1988), we can hypothesize that nonprofit sector may provide more social benefits than is possible in the public sector. According to this theory, nonprofit organizations arise to provide collective goods to people that exhibits preferences other than those of the median voter whereas government provides collective goods in order to meet the needs of the median voter. Hence, nonprofit organizations represent a mechanism to satisfy people who are dissatisfied with the level or quality of some collective goods and services produced by the public sector. Then, nonprofits seem to be better positioned than public organizations to support excluded groups as disabled, unemployed and so on. Similarly, Rose-Ackerman (1996) argues that, compared to nonprofits, "government agencies are usually too constrained by legislative mandates and demands for uniformity" (p. 717).

Second, according to François and Vlassopoulos (2007), nonprofits are less encouraged than government to take advantage on the labour donations of their workers. In fact, the managers of nonprofit firms have more flexibility than government bureaucrats "in choosing the mission and provided services tailored to the needs of the local community". In fact, they are appointed by the community whereas government bureaucrats obey elected politicians and, as a result, might take actions that encourage the likelihood of re-election. In the end, we can hypothesize that nonprofit workers may accept to earn less than they would earn in for-profit and public sectors. The study of wage differentials between these three sectors may therefore allow us to explore these different hypotheses.

\footnotetext{
${ }^{3}$ While public sector is not legally subject to same nondistribution constraint as is nonprofit sector, it is subject to political and legal constraints that also effectively prohibit public organizations from distributing their profits.
} 


\subsection{Other theoretical explanations}

There exist other possible explanations for the observed differences in pay between public and for-profit sectors.

The public sector is subject to political constraints and not to profit constraints. The political system may have different objectives from those of the for-profit sector and may lead to higher wages in the public sector. In fact, public workers do not only produce goods and services but also engage in vote-producing activities. A well-paid workforce can be then in the interest of the politicians (Gunderson, 1979). To justify a higher pay in the public organizations than in the for-profit ones, a larger influence of trade unions in the public sector is also often invoked (Gregory and Borland, 1999).

Another argument concerns the potential existence of compensating wage differentials. According to this argument, wages for similar employees in comparable jobs should be lower in the public sector than in the for-profit one. In fact, public workers benefit from job protection and may enjoy fringe benefits such as longer holidays or more advantageous pensions plans. Since fringe benefits and the risk aversion of workers are rarely observed in empirical studies, they may lead to a forprofit wage premium which is a compensation for the lack of fringe benefits and/or job security (Bellante and Link, 1981; Gregory and Borland, 1999). However, Panizza (1999) discusses an alternative view in which higher job security could rather lead to public sector wage premium. In fact, job security undermines the incentive to work hard and forces the public sector to pay higher wages in an efficiency wage setting.

Contrary to the labour donation theory, there are other theoretical reasons to expect that nonprofit organizations pay higher wages to comparable workers than their for-profit counterparts. According to the theory of property rights, nonprofit organizations will be less prone to minimize costs than for-profit organizations because of nondistribution constraint (Borjas et al., 1983). In this case, the relatively high wages observed in nonprofit sector represent rent-sharing due to attenuated property rights. Another rational for wages to be higher in the nonprofit sector can be found in the efficiency wage theory. Efficiency wages may be more prevalent in the nonprofit sector because of the nature of the output in the sector and the difficulty of monitoring nonprofit worker effort. 


\section{Multinomial logit selection model}

The model used to estimate the wage differentials between the different sectors is a multinomial logit selection model ${ }^{4}$. This model permits us to deal with two distinct problems. First, separated wage equations are estimated for each sector which allows for the possibility that each worker faces an entirely different wage determination process according to his selected sector. Second, some workers may decide on their sector of employment because of the wage differential while others simply prefer to work in nonprofit organizations for nonwage aspects of the job in accordance with the labour donation theory. The wage equations must be estimatied in way that accounts for selectivity. In other words, we allow for endogenous selection into sectors.

The multinomial logit selection model can be described as follows. Each worker is assumed to face three mutually exclusive choices: working in the for-profit $\operatorname{sector}(j=f p)$, working in the nonprofit sector $(j=n p)$ and working in the public sector $(j=p u)$. The 'potential' hourly wage for the $i$ th worker in the $j$ th sector is given by

$$
\ln \mathrm{W}_{\mathrm{j}, \mathrm{i}}=\beta_{\mathrm{j}}^{\prime} \mathrm{X}_{\mathrm{i}}+\varepsilon_{\mathrm{j}, \mathrm{i}}
$$

where $X_{i}$ is a vector of job and worker characteristics that affect the log hourly wage $\left(\ln W_{j, i}\right)$ and $\varepsilon_{j, i} \sim N\left(0, \sigma_{j}^{2}\right)$.

However, sector's choice is not exogenous. In fact, individuals are assumed to select the sector that maximizes expected utility. According to the labour donation theory (Preston, 1989), the maximum utility attainable given each sector will be a function of the $\log$ hourly wage $\left(\ln W_{j, i}\right)$ and social benefits $\left(S B_{j}\right)$ offer by each sector. The $i$ th individual's expected utility from working in sector $\mathrm{j}$ is modelled by the index function

$$
I_{j, i}^{*}=\gamma_{j}^{\prime} Z_{i}+\eta_{j, i}
$$

$Z_{i}$ includes all the variables that may determine the log hourly wage $\left(X_{i}\right)$ plus additional variables that reflect the individual's preferences for the sectors and more

\footnotetext{
${ }^{4}$ This empirical model has been notably used by Gyourko and Tracy (1988) to analyse union wage differentials in the public and private sectors, while controlling for sample selection.
} 
precisely for social benefits offered by the sectors. The $i$ th individual then compares $I_{j, i}$ for all $j=n p, f p, p u$ and chooses that sector for which $I_{j, i}$ is a maximum. This optimization process is captured by the sector indicator function:

$$
I_{i}=j \quad \text { iff } \quad I_{j, i}^{*}>\max _{k \neq j} I_{k, i}^{*}
$$

Following the formulation in Lee (1983), we define the following residual for each individual and each sector:

$$
u_{j, i}=\max _{k \neq j} I_{k, i}^{*}-\eta_{j, i}
$$

From (5), (6) and (7), we obtain a reformulation of the sector indicator function:

$$
I_{i}=j \quad \text { ssi } \quad u_{j, i}<\gamma_{j}^{\prime} Z_{i}
$$

Then, as shown by Domencich and McFadden (1975), the probability that the sector $\mathrm{s}$ will be chosen is given by ${ }^{5}$

$$
\begin{aligned}
\operatorname{Prob}\left(I_{i}=j\right) & =\operatorname{Prob}\left(u_{j, i}<\gamma_{j}^{\prime} Z_{i}\right) \\
& =\frac{\exp \left(\gamma_{j}^{\prime} Z_{i}\right)}{\sum_{k=1}^{3} \exp \left(\gamma_{k}^{\prime} Z_{i}\right)}
\end{aligned}
$$

The worker's choice of sectors is then analysed with a multinomial logit model. We estimate the wage equation in each sector using the generalized two-step procedure presented in Lee (1983):

$$
\begin{aligned}
E\left(\ln W_{j, i} \mid I_{i}=j\right) & =\beta_{j}^{\prime} X_{i}+E\left(\varepsilon_{j, i} \mid I_{i}=j\right) \\
& =\beta_{j}^{\prime} X_{i}+E\left(\varepsilon_{j, i} \mid u_{j, i}<\gamma_{j}^{\prime} Z_{i}\right) \\
& =\beta_{j}^{\prime} X_{i}-\sigma_{j} \rho_{j} \frac{\phi\left\{\Phi^{-1}\left[F_{j}\left(\gamma_{j}^{\prime} Z_{i}\right)\right]\right\}}{F_{j}\left(\gamma_{j}^{\prime} Z_{i}\right)} \\
& =\beta_{j}^{\prime} X_{i}-\sigma_{j} \rho_{j} \lambda_{j, i}
\end{aligned}
$$

\footnotetext{
${ }^{5}$ The disturbances $\eta_{j, i}$ are assumed to be independently and identically distributed with the type I extreme value distribution with cumulative distribution function given by $F\left(\eta_{j, i}<x\right)=\exp [-\exp (x)]$.
} 
Where $\mathrm{F}$ denotes the multinomial logit distribution function. $\Phi($.$) and \phi($.$) are the$ standard normal distribution and density functions respectively. $\rho_{j}$ is the correlation coefficient between $\eta_{\mathrm{j}, \mathrm{i}}$ and $\varepsilon_{\mathrm{j}, \mathrm{i}} \cdot \sigma_{\mathrm{j}}$ is the standard deviation of the error term $\varepsilon_{j, i}$. $\lambda_{j, i}$ represents the selection term.

The model is estimated in two steps. In the first step, we estimate the multinomial logit model (4) by the logit maximum likelihood method to obtain $\hat{\gamma}_{j}$. In the second step, we estimate equation (9) by ordinary least squares (OLS) after substituting $\hat{\gamma}_{j}$ for $\hat{\gamma}_{j}{ }^{6}$.

Estimation of the multinomial logit model in the first step is based on the assumption that probabilities of the alternative choices are independent of each other. In other words, removing any of the alternatives in the model should not alter the relative probabilities of choosing the remaining alternatives. This is commonly known as the property of independence from irrelevant alternatives (IIA). Available tests for IIA start from the premise that if a subset of choices is truly irrelevant, omitting them from the model will not change the estimates using the remaining choices systematically. We have chosen to use Small and Hsiao (1985) test for the IIA assumption. Table 1 displays the results concerning this test using specification of equation (4) described in the next section. It appears that the IIA assumption holds in all cases. In other words, adding or deleting choices does not affect the odds among the remaining choices, and the multinomial logit is the correct model choice.

\section{Description of data and variables}

The data used in this study were taken from the 1994-2001 French Labour Force Survey conducted by INSEE ${ }^{7}$. This survey has the advantage of specifically identifying the nonprofit status of worker.

The sample has been selected to include all employees between the ages of 16 and 65 with a permanent contract. Moreover, we have restricted our attention to

\footnotetext{
${ }^{6}$ The corrected variance-covariance matrix has been derived following the method presented in Lee, Maddala and Trost (1980).

${ }^{7}$ INSEE is the French National Institute for Statistics and Economics Studies.
} 
services sector because nonprofit organizations only move in this sector. In the sector of services, our analysis is also limited to sub-sectors in which the three institutional forms - nonprofit, for-profit and public - coexist $^{8}$. The rationale for the last selection criterion is that we wish to consider homogeneous production techniques and hopefully similar types of jobs. Finally, the working sample consists of 93008 observations. Of these, 11723 refer to individuals in the nonprofit sector, 25009 in the for-profit sector and 56276 in the public sector.

In the wage equations, the dependent variable is the natural logarithm of hourly net wage on the main job. Hourly net wage is calculated as net earnings in the last month divided by 4.33 multiplied by the usual weekly working hours. Some wage premia are not included in this hourly net wage. These premia correspond to any sums of money not paid monthly like thirteen month's salary, Christmas bonus and so on. Nominal values are converted into real terms with a base period of 1990. The explanatory variables assumed to influence wages include sex, marital status, number of children, age, dummy variables for education, tenure at current job ${ }^{9}$, dummy variable indicating if individuals work part-time, occupation, size of firm measured by the number of employees, dummy variable signalling if individuals are employed in the Paris Area, and some working conditions (types of working hours).

The variables included in the choice of the sector equation are the explanatory variables of the potential log hourly net wage ${ }^{10}$. Moreover, to achieve identification of the selection model, it is necessary to include additional variables, called "instruments", which influence sector choice but have no direct effects on wages (i.e., variables in $\mathrm{Z}$ which are not in $\mathrm{X}$ ). Many instruments are suggested.

According to Weisbrod (1983), socioeconomic backgrounds are hypothesized to influence sector's choice. We use the father's occupation as a proxy of socioeconomic backgrounds. We include two dummy variables. The first signals if the worker has a father who works in the public sector. The second indicates if the worker has a father who holds an occupation in the private sector (nonprofit or forprofit) rather directed to social welfare improvement. The occupations in the forprofit sector which we have considered rather directed to social welfare improvement

\footnotetext{
${ }^{8}$ For example, we have excluded sub-sectors like «Transport, storage and communications » and «Financial intermediation » where nonprofit organizations are almost inactive.

${ }^{9}$ Tenure is obtained as the difference between the year of the survey and the year of the start of the current job.

${ }^{10}$ However, job tenure is not considered in the choice of the sector equation because selection must precede tenure at current job.
} 
are for example managers in social and community services, health and social work associate professionals, personal services clerks (like nursing auxiliaries), creative and performing artists. These occupations are mainly present in sectors like health, social services, art and culture where the provision of social benefits is important. Workers engaged in these sectors can derive direct non pecuniary benefits because they have a real concern about the recipient of the services. We expect that having a father who holds an occupation in the private sector rather directed to social welfare improvement will positively influence the probability of selecting nonprofit sector.

We also create two variables indicating the proportion of nonprofit employment and the proportion of public employment in the services sector total employment when the worker has been hired in his current job. The idea is that, according to their year of hire, workers may have greater access to nonprofit and public sectors and presumably lower cost of entry. More particularly, in France, during the 1980s, the Socialist government has supported the emergence of the nonprofit sector and hence the employment in this sector as mechanism through which to implement decentralization and as an important tool for social policy.

Finally, we include a dummy variable measuring if the organization offers nonmonthly wage premia. The idea is that nonprofit workers, because of their preferences for social benefits, are less attracted to this kind of reward than their forprofit and public counterparts.

Table 2 offers summary descriptive statistics of the sample by sector. It shows many significant differences between sectors. For example, public workers earn on average 2.7 per cent more than nonprofit workers who, in turn, earn on average 1.9 per cent more than for-profit workers. There are more part-time workers and female employees in nonprofit sector than in other sectors. Compared to for-profit workers, nonprofit and public workers are older, much more highly educated and have higher job tenure.

\section{Empirical results}

\subsection{Choice and wage equations}


The marginal effect of each variable on the probability of selecting each sector is given in table 3. Several features are worth noting about these effects. As can be seen in the bottom of table 3 , the variables not used in the wage equations have the expected signs. The proportion of nonprofit (respectively public) employment in the services sector total employment influences positively and significantly the probability of selecting the nonprofit (respectively public) sector. Having a father who works in the public sector is associated with a significantly greater probability of being employed in the public sector in line with results on the importance of cultural transmission. This result is in accordance with the one obtained by Audier (2000) and Fougère and Pouget (2003) for France. In the same way, having a father who works in the private sector but holds an occupation rather directed to social welfare improvement influences positively and significantly the probability of selecting the nonprofit and public sectors. Other things equal, nonprofit workers are less likely to be attracted by non-monthly wage premia (variable "bonus") compared to their for-profit and public counterparts. This result means that nonprofit organizations attract workers who have lower interest in monetary rewards in accordance with labour donation theory.

The results for the explanatory variables used in the wage equations also merit some remarks. Being employed part-time increases the probability of selecting the nonprofit sector. Youngers are more likely to be for-profit workers. Considering the level of education, estimates show that education significantly increases the individual's likelihood of being employed in the public sector. Managers have a higher probability of selecting the nonprofit sector while being technicians or employees reduces the likelihood of being in the for-profit sector.

Using the estimation procedure presented in section 3 , the results from table 3 (the coefficients but not the marginal effects) are used to estimate the wage equations with selectivity correction presented in table 4. Selection terms are statistically significant, except for the for-profit sector. The sectors' choice is then endogenous. A negative (positive) estimated coefficient on selection term implies that workers who choose the considered sector have unobserved characteristics which lead them to earn more (less) than a person randomly drawn from the population and assigned to this sector. The human capital variables have the expected signs in the three sectors. Age and job tenure imply the familiar inverted-U shaped wage profile. Returns to education are similarly positively significant. Female workers, compared to male 
workers, receive lower wages. Variables like the number of children, or being married, have also a positive impact on wages. The same is true for characteristics like working in the Paris area or in a large firm (except for the public sector) that imply higher wages.

\subsection{Economy-wide wage differentials}

In a selection model involving more than two choices, the conditional wage differentials (defined as the difference between a worker's expected wage in his preferred sector and his expected wage in his less preferred sector) cannot be estimated because some of the covariance terms required are not identified (see, Gyourko et Tracy, 1988, pp. 240-241). We can only estimate the unconditional wage differentials between nonprofit, for-profit and public sectors. These wage differentials do not take account the average selection effects. Consequently, the impossibility of calculating the conditional wage differentials somewhat restricts the interpretation of the presented wage differentials.

Unconditional wage differentials between nonprofit, for-profit and public sectors are presented in figure 1 and are estimated as follows

$$
\Delta W_{i \rightarrow j}=\left[\frac{E\left(\ln W_{j} \mid \bar{X}_{i}\right)}{E\left(\ln W_{i} \mid \bar{X}_{i}\right)}-1\right] \times 100=\left[\frac{\exp \left(\hat{\beta}_{j} \bar{X}_{i}\right)}{\exp \left(\hat{\beta}_{i} \bar{X}_{i}\right)}-1\right] \times 100
$$

$\Delta W_{i \rightarrow j}$ corresponds to the difference in the returns for the observed characteristics of the average worker of sector $i$ in the labour market sectors $j$ and $i$. In other words, this unconditional wage differential compares on average what the workers of sector $i$ would have earned if they had to work in sector $j$ with what they earn in sector $i$. For example, the first wage differential presented in figure 1 $\left(\Delta W_{p u \rightarrow f p}=-9.5 \%\right)$ compares on average what the public workers $(i=p u)$ would have earned if they had to work in for-profit sector $(j=f p)$ with what they earn in public sector.

The two wage differentials in the bottom of figure 1 support the Preston's theoretical model. In fact, nonprofit workers would have earned $20.1 \%$ and $11.5 \%$ more if they had to work in public sector and for-profit sector respectively. In this sense, our study allows to test more extensively the labour donation theory compared 
to previous studies because it shows that nonprofit workers are willing to work at lower wage that they could have obtained not only in the for-profit sector but also in the public one. In contrast, public workers have chosen the best profitable sector. Considering the for-profit workers, they would have obtained a supplementary wage benefit of $6.9 \%$ in joining the public sector and a wage penalty of $13.0 \%$ in joining the nonprofit sector ${ }^{11}$.

These results suggest a higher pro-social motivation among nonprofit workers than among for-profit and public workers. However, the wage differentials between nonprofit and for-profit sectors may also reflect unmeasured compensating wage differentials across these two organizational forms. For-profit organizations may pay relatively high wages because they offer compensating wage differentials for higher levels of job stress resulting from a greater competitive work environment. In fact, French and Dunlap (1998) found a significant wage premium attributable to job stress. Moreover, nonprofit organizations may offer lower wages in return to higher job security, given the common assumption that the labour market is dominated by risk averse workers rather risk seekers. However, Lanfranchi and Narcy (2008) show that, compared to for-profit workers, nonprofit workers are not significantly more satisfied with the work load, work tension, job stress and job security, other things being equal. More generally, several studies reveal that nonprofit workers enjoy a higher overall job satisfaction than their for-profit counterparts because they gain higher intrinsic utility from their work (Benz, 2005; Lanfranchi and Narcy, 2008...).

More surprisingly, the results seem to show a lack of pro-social motivation among public workers even though they are engaged in the production of services that have a social value. However, the wage settlements in the French public sector are very different from the ones observed in the nonprofit and for-profit sectors. In fact, public pay levels reflect mostly policy orientation and public budgetary constraint. Moreover, the compensation is set by statute with the same pay scales applying to all public workers. Hence, contrary to nonprofit and for-profit workers, it is very difficult for socially motivated workers to donate a portion of the wages they earn even though they would be willing to do so. Therefore, the estimation of wage

\footnotetext{
${ }^{11}$ The results are not sensitive to the inclusion of fixed term contracts in the sample. In fact, the results would have been as follows. The nonprofit workers would have earned $+19.9 \%$ and $+10.1 \%$ more if they had to work in public sector and for-profit sector respectively. Considering the for-profit workers, they would have obtained a supplementary wage benefit of $5.1 \%$ of joining the public sector and a wage penalty of $14.5 \%$ in joining the nonprofit one. If the public workers would have obtained a wage loss of $20.4 \%$ and of $10.7 \%$ if they had been paid like nonprofit and for-profit workers respectively.
} 
may not be the most relevant way to assess pro-social motivation among public workers.

Indeed, donations of labour come in many forms and public organizations may then receive labour donations in a non monetary manner. Donated labour may be also defined as additional effort that goes beyond that required to maintain a standard career path. In this sense, unpaid overtime, e.g., extra hours for which workers do not receive any direct or indirect financial compensation, can be considered as an another proxy of donated labour. Hence, it would be very interesting to compare the magnitude of unpaid overtime between nonprofit, for-profit and public sectors ${ }^{12}$.

The economy-wide wage differentials can represent an average of wage differentials that occur with different magnitudes across different occupations and industries. To investigate this possibility, we turn to an estimation of wage differentials between nonprofit, for-profit and public sectors within different occupations and industries.

\subsection{Wage differentials within occupations and industries}

We next examine wage differentials between nonprofit, for-profit and public sectors within occupations and specific industries. To do so, these wage differentials are calculated using the estimated coefficients of the original model.

Table 5 displays results for occupations. The findings are generally consistent with the ones obtained in the whole economy and presented in figure 1 . We can observe in the bottom of table 5 that, whatever their occupations, nonprofit workers would have earned more if they had to work in public and for-profit sectors. This indicates some cope for labour donations by each occupation. These labour donations are greater for managers and blue collars than they are for technicians, supervisors and employees, more particularly when we consider what nonprofit workers would have earned if they had to work in for-profit sector. These results seem to be in accordance with the argument developed by Preston (1989). In fact, Preston postulated that workers with more control over (like managers) and contact with social benefits production (like blue-collars) are willing to donate more labour.

${ }^{12}$ Unfortunately, the unpaid overtime of workers cannot be observed in the Labour Force Survey. 
Considering the other wage differentials, we can observe that for-profit managers would have obtained the same wage if they had to work in public sector. In the same way, the wage penalty of public workers in joining the for-profit sector is lower for managers than it is for the others occupations. These two results seem to be consistent with the analysis of Lucifora and Meurs (2006) in which they observe that high skilled public workers are paid lower wages with respect to their for-profit counterparts.

It is also interesting to examine the disparities in wage levels in some industries. In fact, as Preston argues, the nonprofit wage penalty should be smaller within specific industries since organizations engaged in the same activities may generate more comparable social benefits and have more similar working conditions. Table 6 summarizes the results for three industries - education; health and social work; other community, social and personal services - where there is a sufficient mix of nonprofit, for-profit and public employment.

The findings are again generally consistent with the ones obtained in the whole economy. The one exception is that there exists no public/for-profit wage differential within other community, social and personal service activities. More precisely, the results show that the nonprofit/for-profit wage differential is smaller in health and social work than in two other industries. This difference is not really surprising because the magnitude of the nonprofit/for-profit wage differential depends on the social benefits differentials between the nonprofit and for-profit organizations (Preston, 1988). Within health and social work industry, the social benefits associated with the service are high, but the social benefits differentials between nonprofit and for-profit firms are likely to be small. Therefore, within this sector, forprofit employees are also willing to accept decreased compensation in order to work in a sector providing high social benefits. However, the persistence of a nonprofit wage penalty even within an industry performing socially desirable activities suggests that an organization that does not have a residual claimant can have a distinct advantage to obtain donations of labour from socially motivated workers. The estimation of public-for-profit wage differential within health and social work industry confirms the for-profit workers' inclination to donate labour within this sector. In fact, the magnitude of the public/for-profit wage differential is higher within health and social work industry than within two other industries. This result 
also suggests that the public sector wage setting seems to be independent of the industry's capacity to generate social benefits.

\section{Conclusion}

In this paper, we have been interested in estimating wage differentials between French nonprofit, for-profit and public sectors. More precisely, we have attempted to measure the relationship between organizational form and donated labour defined as workers' propensity to accept lower wages in return for assisting with production they find social value.

Our results support the Preston's labour donation theory more extensively than previous American studies that have overlooked the public sector. In fact, nonprofit workers are willing to work at lower wage than they could have obtained not only in the for-profit sector but also in the public one. Hence, the nonprofit sector seems to attract workers who have a strong commitment to the nonprofits' social objective and a subordinate interest in monetary gains. Therefore, nonprofit workers may report higher levels of pro-social motivation than for-profit and public counterparts do. On the contrary, our results suggest a lack of pro-social motivation among public workers even though they are engaged in the production of services that have a social value.

However, labour donations may come in many forms and public organizations may receive labour donations from their workers in a non monetary manner. For example, public workers may exhibit higher pro-social motivation than for-profit and nonprofit counterparts if they offer longer unpaid overtime, other things being equal. More generally, in order to provide further empirical evidence on relationship between organizational form and pro-social behaviour, it would be interesting to complement this research by performing analysis using other labour donations measures. This remains an area for further work.

\section{Acknowledgements}

We wish to thank J. Lanfranchi and S. Lotz for the useful comments and suggestions. Any remaining errors are ours. 


\section{References}

Audier, F., (2000) La transmission du statut dans la fonction publique, Économie et Statistique, 337-338, 121-31.

Bellante, D., and A.N. Link (1981) Are public sector workers more risk averse than private sector workers ?, Industrial and Labour Relations Review, 34, 408-12.

Benz, M., (2005) Not for the profit but for the satisfaction? Evidence on worker wellbeing in non-profit firms, Kyklos, 58, 155-76.

Borjas, G., Frech, H.E., and P.B. Ginsburg (1983) Property Rights and Wages: The Case of Nursing Homes, Journal of Human Resources, 17, 231-46.

Domencich, T., and D. McFadden (1975) Urban Travel Demand: A Behavioral Analysis, Amsterdam: North Holland.

Dustmann, C., and A. Van Soest (1998) Public and private sector wages of male workers in Germany, European Economic Review, 42, 1417-41.

Fougère, D., and J. Pouget (2003) Les déterminants économiques de l'entrée dans la fonction publique, Économie et Statistique, 369-370, 15-48.

François, P., and M. Vlassopoulos (2007), Pro-Social Motivation and the delivery of Social Services, forthcoming in CESifo Economic Studies.

French, M.T., and L.J. Dunlap (1998) Compensating Wage Differentials for Job Stress, Applied Economics, 30, 1067-1075.

Frey, B.S., (1997) On the relationship between intrinsic and extrinsic work motivation, International Journal of Industrial Organization, 15, 427-39. 
Gregory, R.G., and J. Borland (1999) Recent developments in public sector labour markets, in O. Ashenfelter and D. Card, eds., Handbook of Labour Economics, Amsterdam, Elsevier Science.

Gunderson, M., (1979) Earnings differentials between the public and private sectors, Canadian Journal of Economics, 12, 229-53.

Gyourko, J., and J. Tracy (1988) An Analysis of Public- and Private- Sector Wages allowing for Endogenous Choices of both Government and Union Status, Journal of Labour Economics, 6, 229-53.

Hallock, K.F., (2000) Compensation in Nonprofit Organizations, Research in Personnel and Human Resources Management, 19, 243-94.

Hansman, H., (1980) The Role of Nonprofit Enterprise, Yale Law Journal, 89, 835901.

Hartog, J, and H. Oosterbeek (1993) Public and private sector wages in the Netherlands, European Economic Review, 37, 97-114.

Holtmann, A.G., and T.L. Idson (1993) Wage Determination of Registered Nurses in Proprietary and Nonprofit Nurses Homes, Journal of Human Resources, 28, 55-79.

Jann, B. (2005) Standard Errors for the Blinder-Oaxaca Decomposition, Working Paper, 3rd German Stata Users Group Meeting in Berlin.

Lee, L.F., (1983) Generalized Econometric Models with Selectivity, Econometrica, 51, 507-12.

Lee, L.F., Maddala, G.S., and R. Trost (1980) Asymptotic Covariance Matrices of Two-Stage Probit and Two-Stage Tobit Methods for Simultaneous Equations models with Selectivity, Econometrica, 48, 491-503. 
Mocan, H.N., and E. Teikin (2003) Nonprofit Sector and Part-Time Work : An Analysis of Employer-Employee Matched Data of Childcare Workers, Review of Economics and Statistics, 85, 38-50.

Noguchi, H., Shimizutani, S., and W. Suzuki (2008) Nonprofit Wage Premium in the Japanese Child Care Market: Evidence from Employer-Employee Matched Data, Applied Economics Letters (forthcoming).

Panizza, U., (1999) Why do lazy people make more money? The strange case of the public sector wage premium, Working Paper 403. Washington, DC, United States: Inter-American Development Bank, Research Department.

Prescott, D., and B. Wandschneider (1999) Public/Private Sector Wage Differentials in Canada- Evidence from the 1991 and 1992 Surveys of Consumer Finance, Applied Economics, 31, 723-31.

Preston, A.E. (1988) The Effects of porperty Rights on Labour Costs of Nonprofit Firms: An Application to the Day Care Industry, Journal of Industrial Economics, 36, 337-350.

Preston, A.E., (1989) The Nonprofit Worker in a For-Profit World, Journal of Labour Economics, 7, 438-63.

Rose-Ackerman, S., (1996), Altruism, Nonprofits, and Economic Theory, Journal of Economic Literature, 34, 701-728.

Ruhm, C.J., and C. Borkoski (2003) Compensation in the Nonprofit Sector, Journal of Human Resources, 38, 992-1021.

Salamon, L.M., Anheir, H.K., List, R., Toepler, S., Sokolowski, W., and Associates (1999) Global Civil Society: Dimensions of the Nonprofit Sector, Johns Hopkins Center for Civil Society Studies: Baltimore, MD. 
Small, K.A., and C. Hsiao (1985) Multinomial Logit Specification Tests, International Economic Review, 26, 619-27.

Weisbrod, B.A., (1983) Nonprofit and Proprietary Sector Behavior: Wage Differentials among Lawyers, Journal of Labour Economics, 1, 246-63.

Weisbrod, B.A., (1988) The Nonprofit Economy, Cambridge MA., Harvard University Press. 
Table 1 - Small-Hsiao test of the IIA assumption

\begin{tabular}{cccccc}
\hline \hline Sector omitted & $\operatorname{lnL}[$ full] & $\operatorname{lnL}[\mathbf{o m i t}]$ & SH & P>chi2 & Evidence \\
\hline For-profit sector & $-1,35 \mathrm{E}+4$ & $-1,35 \mathrm{E}+4$ & 42,830 & 0,170 & for $\mathrm{H}_{0}$ \\
Nonprofit sector & $-2,07 \mathrm{E}+4$ & $-2,07 \mathrm{E}+4$ & 26,360 & 0,853 & for $\mathrm{H}_{0}$ \\
Public sector & $-1,05 \mathrm{E}+4$ & $-1,04 \mathrm{E}+4$ & 43,260 & 0,159 & for $\mathrm{H}_{0}$ \\
\hline \hline
\end{tabular}

Source: INSEE, French Labour Force Survey (1994 to 2001).

Note: The basic idea of the Small and Hsiao (1985) test is that if the IIA assumption holds, the loglikelihood for the unrestricted model (lnL[full]) will not be very different from the log-likelihood for the restricted model (lnL[omit]). This latter model is created by dropping one choice alternative.

The hypotheses are:

$\mathrm{H}_{0}$ : IIA assumption is not violated.

$\mathrm{H}_{1}$ : IIA assumption is violated.

The test statistics is:

$\mathrm{SH}=-2[\operatorname{lnL}[$ full] $-\operatorname{lnL}[\mathrm{omit}]]$

$\mathrm{SH}$ is asymptotically chi-square distributed with degrees of freedom equal to the number of independent variables plus one. 
Table 2 - Descriptive statistics

\begin{tabular}{|c|c|c|c|}
\hline Variable & $\begin{array}{l}\text { Nonprofit } \\
\text { sector }\end{array}$ & $\begin{array}{l}\text { For-profit } \\
\text { sector }\end{array}$ & Public sector \\
\hline Log net hourly wage & 3.71 & 3.64 & 3.83 \\
\hline (in 1990 French Francs) & $(0.32)$ & $(0.33)$ & $(0.31)$ \\
\hline Part-time work (\%) & 30.6 & 23.3 & 16.0 \\
\hline Female (\%) & 71.6 & 63.1 & 64.1 \\
\hline Married or cohabiting (\%) & 73.8 & 71.6 & 77.2 \\
\hline Number of children & $\begin{array}{c}0.8 \\
(1.0)\end{array}$ & $\begin{array}{c}0.8 \\
(1.0)\end{array}$ & $\begin{array}{c}0.8 \\
(1.0)\end{array}$ \\
\hline Age (years) & $\begin{array}{l}40.8 \\
(9.6)\end{array}$ & $\begin{array}{l}37.4 \\
(9.9)\end{array}$ & $\begin{array}{l}41.2 \\
(9.0)\end{array}$ \\
\hline Job tenure (years) & $\begin{array}{l}9.5 \\
(7.9)\end{array}$ & $\begin{array}{l}7.7 \\
(7.8)\end{array}$ & $\begin{array}{l}14.2 \\
(9.3)\end{array}$ \\
\hline \multicolumn{4}{|l|}{ Qualifications (\%): } \\
\hline No qualification & 20.6 & 20.6 & 18.3 \\
\hline General lower secondary & 6.5 & 8.0 & 7.2 \\
\hline Vocational lower secondary & 26.2 & 30.0 & 25.9 \\
\hline High school degree & 13.3 & 16.1 & 13.3 \\
\hline Undergraduate level & 22.0 & 16.2 & 19.8 \\
\hline Above undergraduate & 11.4 & 9.1 & 15.5 \\
\hline \multicolumn{4}{|l|}{ Occupations (\%): } \\
\hline Blue-collar & 10.3 & 17.4 & 10.1 \\
\hline Employee & 42.8 & 46.4 & 41.7 \\
\hline Technicians, supervisors & 36.8 & 24.7 & 33.4 \\
\hline Managers & 10.1 & 11.5 & 14.8 \\
\hline \multicolumn{4}{|l|}{ Firm sizes $(\%)$ : } \\
\hline $1-9$ & 25.4 & 37.5 & 36.8 \\
\hline $10-49$ & 23.7 & 22.7 & 9.4 \\
\hline $50-499$ & 32.1 & 22.2 & 20.9 \\
\hline$>499$ & 18.8 & 17.6 & 32.9 \\
\hline Employed in the Paris area (\%) & 12.5 & 22.1 & 13.2 \\
\hline \multicolumn{4}{|l|}{ Working conditions $(\%)$ : } \\
\hline Night work & 10.7 & 14.0 & 14.6 \\
\hline Shift work & 7.4 & 6.3 & 8.4 \\
\hline Sunday work & 32.1 & 31.4 & 37.9 \\
\hline Variable working time & 30.6 & 28.2 & 26.6 \\
\hline Nonprofit employment (\%) & 8.5 & 8.8 & 7.5 \\
\hline Public employment (\%) & 39.1 & 36.1 & 46.1 \\
\hline \multicolumn{4}{|l|}{ Father's occupation (\%): } \\
\hline Public sector & 14.2 & 13.1 & 18.3 \\
\hline $\begin{array}{l}\text { Directed to social welfare improvement } \\
\text { in private sector }\end{array}$ & 34.9 & 30.1 & 31.9 \\
\hline Bonus $(\%)$ & 36.0 & 47.0 & 54.3 \\
\hline $\mathbf{N}$ & 11723 & 25009 & 56276 \\
\hline
\end{tabular}

Source: INSEE, French Labour Force Survey (1994 to 2001).

Note: Standard deviations are in parentheses. 
Table 3 - Multinomial logit sector choice model (marginal effects)

\begin{tabular}{|c|c|c|c|c|c|c|}
\hline \multirow[t]{2}{*}{ Variable } & \multicolumn{2}{|c|}{ Nonprofit sector } & \multicolumn{2}{|c|}{ For-profit sector } & \multicolumn{2}{|c|}{ Public sector } \\
\hline & Coef. & t-value & Coef. & $\mathrm{t}$-value & Coef. & t-value \\
\hline Intercept & -0.379 & (16.26) & 1.048 & (32.61) & -0.669 & $(17.75)$ \\
\hline Part-time work & 0.057 & (22.14) & 0,050 & $(12.65)$ & -0.107 & $(23.40)$ \\
\hline Female & 0.013 & $(4.99)$ & $-0.003 *$ & $(0.89)$ & -0.010 & $(2.36)$ \\
\hline Married or cohabiting & -0.009 & $(3.80)$ & -0.011 & (2.94) & 0.020 & $(4.82)$ \\
\hline Number of children & -0.006 & (5.39) & -0.011 & $(6.12)$ & 0.017 & $(8.65)$ \\
\hline Age & 0.002 & $(2.30)$ & -0.026 & $(18.96)$ & 0.024 & $(14.58)$ \\
\hline $\mathrm{Age}^{2} / 100$ & $-0.001 *$ & $(0.59)$ & 0.027 & (16.01) & -0.026 & (13.28) \\
\hline \multicolumn{7}{|l|}{ Qualifications: } \\
\hline No qualification & \multicolumn{2}{|c|}{ Ref. } & \multicolumn{2}{|c|}{ Ref. } & \multicolumn{2}{|c|}{ Ref. } \\
\hline $\begin{array}{l}\text { General lower } \\
\text { secondary }\end{array}$ & $-0.006^{*}$ & $(1.16)$ & $0.010 *$ & $(1.52)$ & $-0.004 *$ & $(0.56)$ \\
\hline $\begin{array}{l}\text { Vocational lower } \\
\text { secondary }\end{array}$ & $0.005^{*}$ & $(1.67)$ & $-0.002 *$ & $(0.46)$ & $-0.003 *$ & $(0.63)$ \\
\hline High school degree & -0.008 & $(2.05)$ & $-0.008 *$ & $(1.43)$ & 0.016 & $(2.43)$ \\
\hline Undergraduate level & $-0.005^{*}$ & $(1.01)$ & -0.075 & (12.44) & 0.080 & (11.40) \\
\hline Above undergraduate & -0.032 & $(6.04)$ & -0.218 & (28.57) & 0.250 & $(28.89)$ \\
\hline \multicolumn{7}{|l|}{ Occupations: } \\
\hline Blue-collar & \multicolumn{2}{|c|}{ Ref. } & \multicolumn{2}{|c|}{ Ref. } & \multicolumn{2}{|c|}{ Ref. } \\
\hline Employee & 0.015 & $(3.89)$ & -0.077 & $(15.75)$ & 0.062 & $(10.38)$ \\
\hline $\begin{array}{l}\text { Technicians, } \\
\text { supervisors }\end{array}$ & 0.057 & (12.92) & -0.086 & $(14.82)$ & 0.029 & $(4.24)$ \\
\hline Managers & 0.023 & $(4.05)$ & $-0.001 *$ & $(0.31)$ & -0.022 & $(2.57)$ \\
\hline \multicolumn{7}{|l|}{ Firm sizes: } \\
\hline $1-9$ & \multicolumn{2}{|c|}{ Ref. } & \multicolumn{2}{|c|}{ Ref. } & \multicolumn{2}{|c|}{ Ref. } \\
\hline $10-49$ & 0.110 & $(36.10)$ & 0.109 & $(24.87)$ & -0.219 & $(41.46)$ \\
\hline $50-499$ & 0.093 & $(33.42)$ & -0.014 & (3.43) & -0.079 & $(17.16)$ \\
\hline$>499$ & 0.022 & $(6.76)$ & -0.113 & $(26.82)$ & 0.091 & 19.21) \\
\hline $\begin{array}{l}\text { Employed in the Paris } \\
\text { area }\end{array}$ & -0.014 & $(4.53)$ & 0.125 & $(31.89)$ & -0.111 & $(23.07)$ \\
\hline \multicolumn{7}{|l|}{ Working conditions : } \\
\hline Night work & -0.025 & $(6.61)$ & 0.032 & $(6.41)$ & $-0.007 *$ & $(1.29)$ \\
\hline Shift work & 0.028 & $(6.35)$ & $-0.012 *$ & $(1.88)$ & -0.016 & $(2.20)$ \\
\hline Sunday work & -0.017 & $(6.51)$ & -0.055 & $(14.60)$ & 0.072 & $(16.74)$ \\
\hline Variable working time & 0.024 & $(9.70)$ & 0.025 & $(6.80)$ & -0.049 & (11.67) \\
\hline Nonprofit employment & 0.018 & $(16.60)$ & -0.009 & $(5.74)$ & -0.009 & $(5.36)$ \\
\hline Public employment & -0.001 & $(3.30)$ & -0.009 & $(38.86)$ & 0.010 & (35.97) \\
\hline \multicolumn{7}{|l|}{ Father's occupation } \\
\hline Public sector & -0.013 & $(4.02)$ & -0.068 & $(15.40)$ & 0.081 & $(16.15)$ \\
\hline $\begin{array}{l}\text { Directed to social } \\
\text { welfare improvement } \\
\text { in private sector }\end{array}$ & 0.009 & $(3.88)$ & -0.018 & $(5.29)$ & 0.009 & $(2.26)$ \\
\hline Bonus & -0.066 & $(29.94)$ & 0.016 & $(5.10)$ & 0.050 & $(14.06)$ \\
\hline Log likelihood & \multicolumn{6}{|c|}{-73738.03} \\
\hline $\mathrm{N}$ & \multicolumn{6}{|c|}{93008} \\
\hline
\end{tabular}

Source: INSEE, French Labour Force Survey (1994 to 2001).

Note: The specification includes as set of year dummies. Absolute $\mathrm{t}$-values are in parentheses. $*$ not significant at $5 \%$. 
Table 4 - Wage equations estimates with selectivity correction by sector of employment

\begin{tabular}{|c|c|c|c|c|c|c|}
\hline \multirow[t]{2}{*}{ Variables } & \multicolumn{2}{|c|}{ Nonprofit sector } & \multicolumn{2}{|c|}{ For-profit sector } & \multicolumn{2}{|c|}{ Public sector } \\
\hline & Coef. & t-value & Coef. & t-value & Coef. & t-value \\
\hline Intercept & 2.627 & (52.69) & 2.780 & (97.80) & 3.007 & (98.67) \\
\hline Part-time work & -0.043 & $(7.37)$ & $-0.04 *$ & (11.73) & -0.047 & (16.70) \\
\hline Female & -0.056 & (10.68) & -0.061 & (18.68) & -0.059 & $(29.42)$ \\
\hline Married or cohabiting & 0.022 & $(4.51)$ & 0.014 & $(4.54)$ & 0.012 & $(5.97)$ \\
\hline Number of children & 0.011 & $(4.67)$ & 0.012 & $(7.52)$ & 0.023 & $(23.51)$ \\
\hline Age & 0.019 & (10.08) & 0.022 & (15.19) & 0.014 & (15.39) \\
\hline $\mathrm{Age}^{2} / 100$ & -0.017 & $(7.53)$ & -0.021 & $(12.75)$ & -0.012 & (11.16) \\
\hline Job tenure & 0.011 & $(12.75)$ & 0.011 & (14.37) & 0.007 & $(15.15)$ \\
\hline Job tenure $2 / 100$ & -0.010 & $(3.25)$ & $-0.005^{*}$ & $(2.34)$ & $0.002 *$ & $(2.39)$ \\
\hline \multicolumn{7}{|l|}{ Qualifications: } \\
\hline No qualification & \multicolumn{2}{|c|}{ Ref. } & \multicolumn{2}{|c|}{ Ref. } & \multicolumn{2}{|c|}{ Ref. } \\
\hline $\begin{array}{l}\text { General lower } \\
\text { secondary }\end{array}$ & 0.117 & $(12.85)$ & 0.071 & $(12.43)$ & 0.100 & $(27.59)$ \\
\hline $\begin{array}{l}\text { Vocational lower } \\
\text { secondary }\end{array}$ & 0.146 & $(24.28)$ & 0.083 & (21.04) & 0.088 & $(35.06)$ \\
\hline High school degree & 0.209 & $(27.25)$ & 0.139 & $(28.92)$ & 0.165 & $(51.06)$ \\
\hline Undergraduate level & 0.284 & $(37.65)$ & 0.214 & $(37.51)$ & 0.225 & $(62.41)$ \\
\hline Above undergraduate & 0.297 & $(31.46)$ & 0.258 & $(26.20)$ & 0.268 & (51.63) \\
\hline \multicolumn{7}{|l|}{ Occupations: } \\
\hline Blue-collar & \multicolumn{2}{|c|}{ Ref. } & \multicolumn{2}{|c|}{ Ref. } & \multicolumn{2}{|c|}{ Ref. } \\
\hline Employee & 0.065 & $(8.50)$ & 0.034 & $(7.30)$ & 0.029 & $(8.94)$ \\
\hline $\begin{array}{l}\text { Technicians, } \\
\text { supervisors }\end{array}$ & 0.259 & (29.17) & 0.207 & $(36.87)$ & 0.223 & $(61.52)$ \\
\hline Managers & 0.385 & (36.13) & 0.405 & $(63.26)$ & 0.364 & $(80.06)$ \\
\hline \multicolumn{7}{|l|}{ Firm sizes : } \\
\hline $1-9$ & \multicolumn{2}{|c|}{ Ref. } & \multicolumn{2}{|c|}{ Ref. } & \multicolumn{2}{|c|}{ Ref. } \\
\hline $10-49$ & 0.060 & $(7.69)$ & 0.021 & $(4.63)$ & -0.012 & $(2.67)$ \\
\hline $50-499$ & 0.071 & $(9.30)$ & 0.032 & $(8.27)$ & $0.003 *$ & $(1.33)$ \\
\hline$>499$ & 0.085 & (12.30) & 0.048 & $(8.66)$ & 0.014 & $(5.81)$ \\
\hline $\begin{array}{l}\text { Employed in the Paris } \\
\text { area }\end{array}$ & 0.086 & (13.73) & 0.124 & $(23.63)$ & 0.061 & $(21.44)$ \\
\hline \multicolumn{7}{|l|}{ Working conditions : } \\
\hline Night work & 0.027 & $(3.84)$ & 0.016 & $(3.53)$ & 0.045 & $(16.81)$ \\
\hline Shift work & 0.040 & $(4.82)$ & $0.009 *$ & $(1.45)$ & 0.032 & $(9.69)$ \\
\hline Sunday work & 0.023 & $(4.58)$ & $-0.005^{*}$ & $(1.25)$ & 0.032 & (14.69) \\
\hline Variable working time & $-0.008 *$ & $(1.75)$ & -0.011 & $(3.38)$ & 0.013 & $(6.12)$ \\
\hline Selection term & -0.072 & $(5.45)$ & $0.018 *$ & $(1.21)$ & 0.048 & $(4.92)$ \\
\hline $\mathrm{R}^{2}$ & \multicolumn{2}{|c|}{0.57} & \multicolumn{2}{|c|}{0.60} & \multicolumn{2}{|c|}{0.62} \\
\hline $\mathrm{N}$ & \multicolumn{2}{|c|}{11723} & \multicolumn{2}{|c|}{25009} & \multicolumn{2}{|c|}{56276} \\
\hline
\end{tabular}

Source: INSEE, French Labour Force Survey (1994 to 2001).

Note: The specification includes a set of industry and year dummies. Absolute t-values are in parentheses. $*$ not significant at $5 \%$. 
Figure 1 - What the workers would have earned if they had to work in an another sector

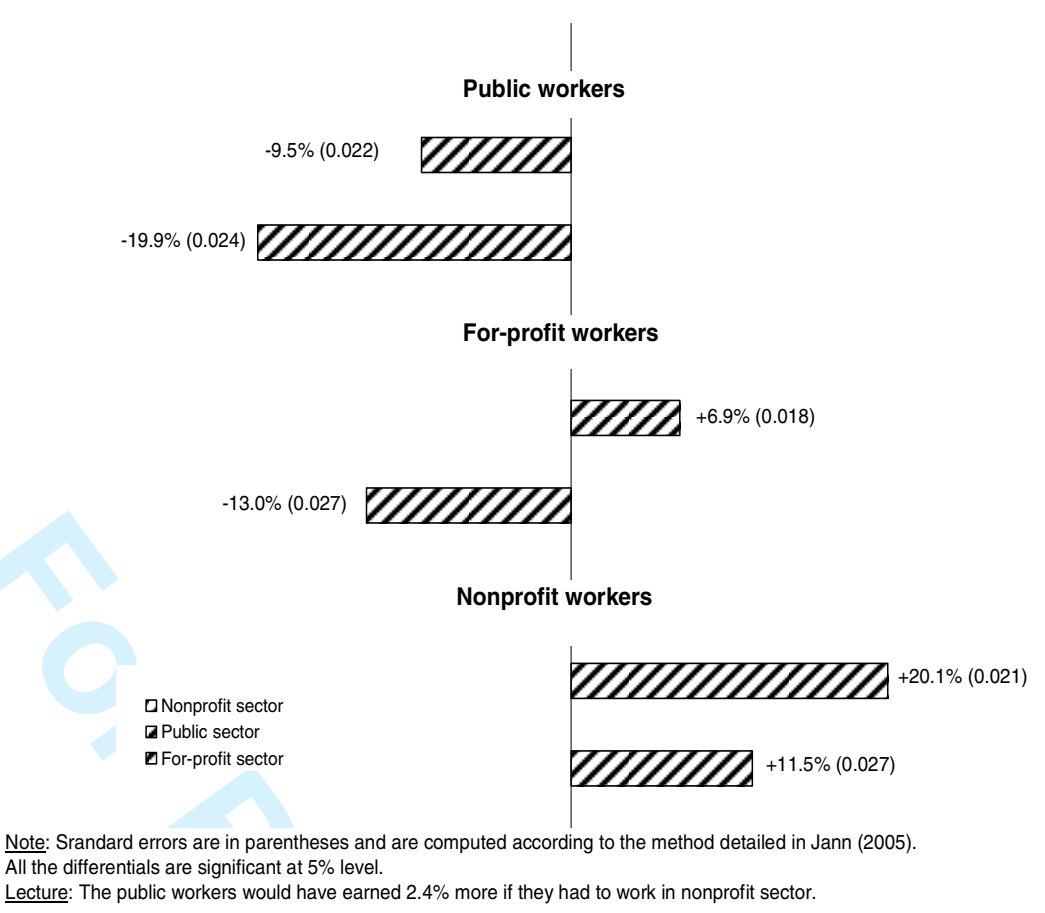

Table 5 - Wage differentials by occupations

\begin{tabular}{|c|c|c|c|c|}
\hline & Managers & $\begin{array}{l}\text { Technicians, } \\
\text { supervisors }\end{array}$ & Employees & Blue-collars \\
\hline \multicolumn{5}{|l|}{ Public workers } \\
\hline For-profit sector & $\begin{array}{l}-\mathbf{6 . 0 \%} \\
(0.024)\end{array}$ & $\begin{array}{l}-11.0 \% \\
(0.024)\end{array}$ & $\begin{array}{l}-9.4 \% \\
(0.021)\end{array}$ & $\begin{array}{l}-9.8 \% \\
(0.020)\end{array}$ \\
\hline Nonprofit sector & $\begin{array}{l}\mathbf{- 2 2 . 3 \%} \\
(0.026)\end{array}$ & $\begin{array}{l}-18.3 \% \\
(0.023)\end{array}$ & $\begin{array}{l}-19.5 \% \\
(0.025)\end{array}$ & $\begin{array}{l}-23.3 \% \\
(0.028)\end{array}$ \\
\hline \multicolumn{5}{|l|}{ For-profit workers } \\
\hline Public sector & $\begin{array}{l}-0.1 \% * \\
(0.019)\end{array}$ & $\begin{array}{l}+8.5 \% \\
(0.020)\end{array}$ & $\begin{array}{l}+7.9 \% \\
(0.018)\end{array}$ & $\begin{array}{l}+6.6 \% \\
(0.017)\end{array}$ \\
\hline Nonprofit sector & $\begin{array}{l}-18.7 \% \\
(0.030)\end{array}$ & $\begin{array}{l}-10.1 \% \\
(0.028)\end{array}$ & $\begin{array}{l}-11.9 \% \\
(0.028)\end{array}$ & $\begin{array}{l}-16.2 \% \\
(0.028)\end{array}$ \\
\hline \multicolumn{5}{|l|}{ Nonprofit workers } \\
\hline Public sector & $\begin{array}{l}+21.8 \% \\
(0.024)\end{array}$ & $\begin{array}{l}+18.9 \% \\
(0.020)\end{array}$ & $\begin{array}{l}+19.6 \% \\
(0.021)\end{array}$ & $\begin{array}{l}+24.8 \% \\
(0.024)\end{array}$ \\
\hline For-profit sector & $\begin{array}{l}+20.0 \% \\
(0.030)\end{array}$ & $\begin{array}{l}+7.9 \% \\
(0.028)\end{array}$ & $\begin{array}{l}+11.5 \% \\
(0.027)\end{array}$ & $\begin{array}{l}+17.3 \% \\
(0.028)\end{array}$ \\
\hline $\mathbf{N}$ & 12405 & 29296 & 40073 & 11234 \\
\hline
\end{tabular}

Source: INSEE, French Labour Force Survey (1994 to 2001).

Note: Standard errors are in parentheses and are computed according to the method detailed in Jann (2005). * not significant at 5\% level.

Lecture: The wage differentials in bold mean that the public managers would have earned $6.0 \%$ and $22.3 \%$ less if they had to work in for-profit sector and nonprofit sector respectively. 
Table 6 - Wage differentials for specific industries

\begin{tabular}{|c|c|c|c|}
\hline & Education & $\begin{array}{l}\text { Health and } \\
\text { social work }\end{array}$ & $\begin{array}{c}\text { Other community, } \\
\text { social and personal } \\
\text { service activities }\end{array}$ \\
\hline \multicolumn{4}{|l|}{ Public workers } \\
\hline For-profit sector & $\begin{array}{l}-7.3 \% \\
(0.024)\end{array}$ & $\begin{array}{l}-10.0 \% \\
(0.024)\end{array}$ & $\begin{array}{l}+0.7 \% * \\
(0.022)\end{array}$ \\
\hline Nonprofit sector & $\begin{array}{l}\mathbf{- 2 0 . 1 \%} \\
(0.024)\end{array}$ & $\begin{array}{l}-16.0 \% \\
(0.023)\end{array}$ & $\begin{array}{l}-16.4 \% \\
(0.026)\end{array}$ \\
\hline \multicolumn{4}{|l|}{ For-profit workers } \\
\hline Public sector & $\begin{array}{l}+8.6 \% \\
(0.020)\end{array}$ & $\begin{array}{l}+12.1 \% \\
(0.019)\end{array}$ & $\begin{array}{c}-0.8 \% \\
(0.019)\end{array}$ \\
\hline Nonprofit sector & $\begin{array}{l}-13.2 \% \\
(0.028)\end{array}$ & $\begin{array}{l}-7.7 \% \\
(0.027)\end{array}$ & $\begin{array}{l}-16.0 \% \\
(0.028)\end{array}$ \\
\hline \multicolumn{4}{|l|}{ Nonprofit workers } \\
\hline Public sector & $\begin{array}{l}+23.1 \% \\
(0.022)\end{array}$ & $\begin{array}{l}+19.5 \% \\
(0.021)\end{array}$ & $\begin{array}{l}+18.8 \% \\
(0.024)\end{array}$ \\
\hline For-profit sector & $\begin{array}{l}+14.4 \% \\
(0.029)\end{array}$ & $\begin{array}{l}+7.8 \% \\
(0.027)\end{array}$ & $\begin{array}{l}+19.2 \% \\
(0.028)\end{array}$ \\
\hline $\mathbf{N}$ & 19393 & 27405 & 5528 \\
\hline
\end{tabular}

Source: INSEE, French Labour Force Survey (1994 to 2001).

Note: Standard errors are in parentheses and are computed according to the method detailed in Jann (2005). * not significant at $5 \%$ level.

Lecture: The wage differentials in bold mean that in the education industry the public workers would have earned $7.3 \%$ and $20.1 \%$ less if they had to work for a for-profit organization and a nonprofit organization respectively. 